\title{
Mouse Spermatogenesis Reflects the Unity and Diversity of Tissue Stem Cell Niche Systems
}

\author{
Shosei Yoshida \\ Division of Germ Cell Biology, National Institute for Basic Biology, National Institutes of Natural Sciences; and \\ Department of Basic Biology, School of Life Science, SOKENDAI (Graduate University for Advanced Studies), \\ Okazaki, Aichi 444-8787, Japan \\ Correspondence: shosei@nibb.ac.jp
}

\begin{abstract}
Mouse spermatogenesis is supported by spermatogenic stem cells (SSCs). SSCs maintain their pool while migrating over an open (or facultative) niche microenvironment of testicular seminiferous tubules, where ligands that support self-renewal are likely distributed widely. This contrasts with the classic picture of closed (or definitive) niches in which stem cells are gathered and the ligands are highly localized. Some of the key properties observed in the dynamics of SSCs in the testicular niche in vivo, which show the flexible and stochastic (probabilistic) fate behaviors, are found to be generic for a wide range of, if not all, tissue stem cells. SSCs also show properties characteristic of an open niche-supported system, such as high motility. Motivated by the properties of SSCs, in this review, I will reconsider the potential unity and diversity of tissue stem cell systems, with an emphasis on the varying degrees of ligand distribution and stem cell motility.
\end{abstract}

\section{OVERVIEW OF MOUSE SPERMATOGENESIS}

$M$ ouse spermatogenesis is supported by the robust and active functions of spermatogenic (spermatogonial) stem cells (SSCs). Spermatogenesis takes place in the seminiferous tubules (precisely, convoluted seminiferous tubules) packed within the testicular capsule (Fig. 1A; Russell et al. 1990; Yoshida 2019). Seminiferous tubules have a simple tube-like architecture with a diameter of 150-200 $\mu \mathrm{m}$. A single mouse testis has $\sim 1.7$-m-long seminiferous tubules comprised of $\sim 10$ separate loops (Fig. 1A). Throughout their length and circumference, seminiferous tubules present a uniform tissue organization (Fig. 1B,C). Their structural framework is primarily based on highly specialized somatic cells called Sertoli cells, which consist of an epithelium with a prominent basement membrane and tight junction. The epithelial sheet of Sertoli cells nourishes all the stages of spermatogenic cells, together forming a composite "seminiferous epithelium." Spermatogonia, the mitotic germ cells including SSCs, are located within the "basal compartment," the gap between the junctional complex and basement membrane (Russell et al. 1990; Meistrich and van Beek 1993; Yoshida 2018a). At the beginning of meiosis, these cells translocate across the junction to the adluminal compartment and undergo meiotic divisions to form haploid spermatids, which then mature into spermatozoa that

Editors: Cristina Lo Celso, Kristy Red-Horse, and Fiona M. Watt

Additional Perspectives on Stem Cells: From Biological Principles to Regenerative Medicine available at www.cshperspectives.org

Copyright (C) 2020 Cold Spring Harbor Laboratory Press; all rights reserved; doi: 10.1101/cshperspect.a036186

Cite this article as Cold Spring Harb Perspect Biol 2020;12:a036186 
S. Yoshida

A

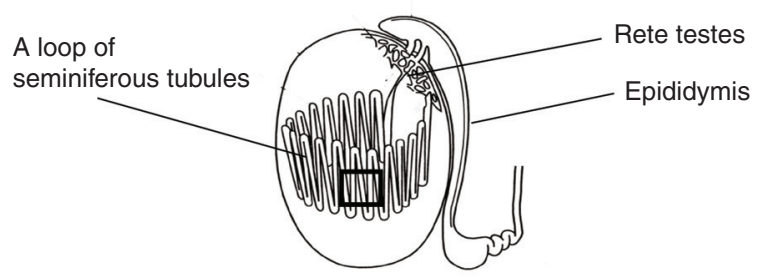

B

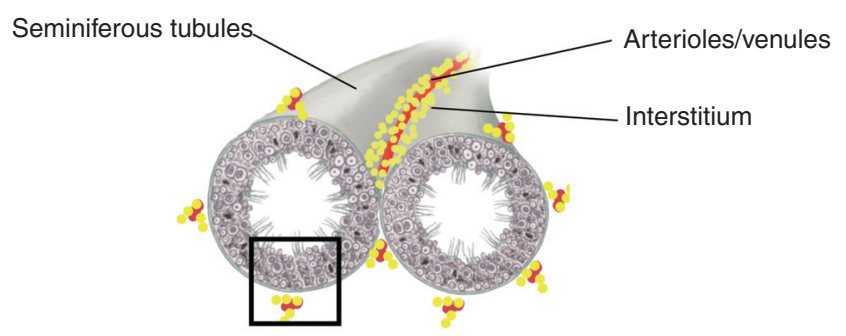

C

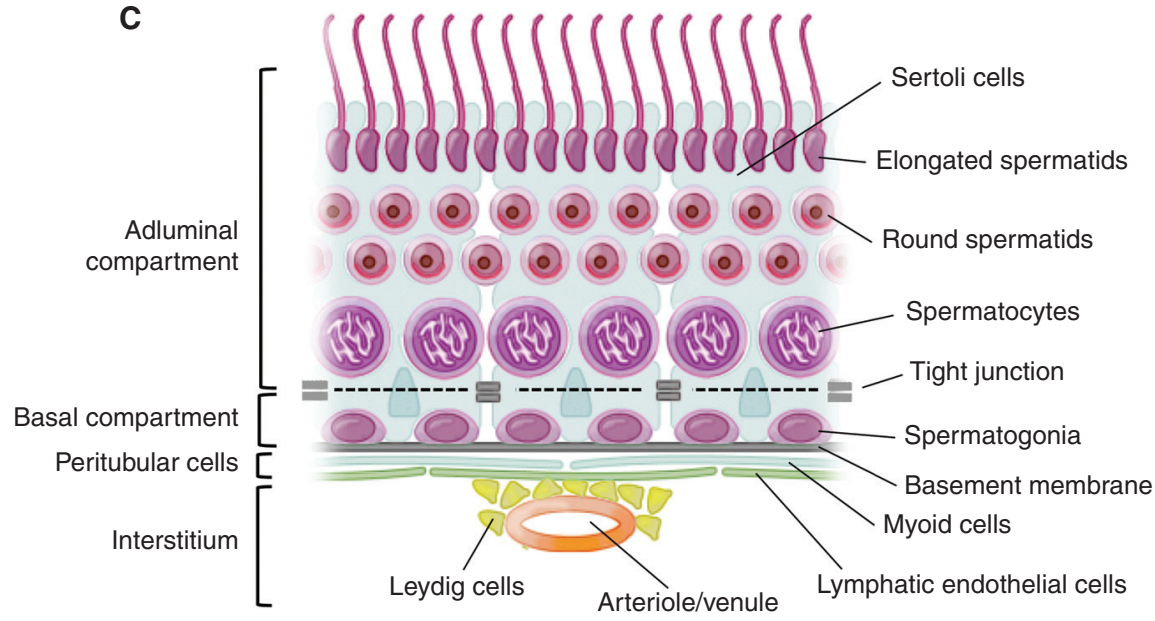

Figure 1. Tissue organization of mouse testes and seminiferous tubules. (A) Macroscopic view of a mouse testis. In the testicular capsule (tunica albuginea), long convoluted seminiferous tubules with a total length of $\sim 1.7 \mathrm{~m}$ per testes are tightly packed as $\sim 10$ separate loops connecting to rete testes, the common outlet of sperm. Only a single loop is shown. (B) A pair of seminiferous tubules (rectangle in $A$ ), with a vasculature network of arterioles and venules (red) and surrounding interstitial cells (including testosterone-producing Leydig cells and macrophages; yellow), which together comprise the interstitium between the tubules. ( $C$ ) Tissue architecture of a part of seminiferous epithelium (rectangle in $B$ ). Within the anatomical framework composed of somatic cell types (e.g., Sertoli cells, peritubular myoid, and lymphatic endothelial cells), which separate adluminal and basal compartments, all the stages of germ cells show a stratified organization. The spermatogonia (mitotic cells) are located in the basal compartment, whereas meiotic spermatocytes and haploid round and elongating spermatids are in the adluminal compartment. ( $B$ and $C$ from Yoshida 2019; modified, with permission, from the author.)

are eventually released into the lumen. The entire process of spermatogenesis takes approximately 35 days and 60 days in mice and humans, respectively. Such simple and homogeneous cell arrangements and tissue configurations provide an invaluable opportunity for investigating stem cell behavior in the basal compartment, in a reproducible manner suitable for quantitative and statistical analyses.

SSCs comprise a small fraction of spermatogonia and are located within the basal compartment. In addition to Sertoli cells and the 
basement membrane, an ensemble of other somatic cells including peritubular myoid cells, lymphatic endothelial cells, interstitial cells, and vasculature, as well as differentiating germ cells, are implicated in the regulation of SSCs in the basal compartment (Fig. 1C; for review, see Yoshida 2018a).

\section{SSC IDENTITY AND REGULATION}

SSC activity resides within a minor fraction of spermatogonia called "undifferentiated spermatogonia" $\left(\mathrm{A}_{\text {undiff }}\right)$, which show heterogeneous topology (Fig. 2A; Russell et al. 1990; Meistrich and van Beek 1993; de Rooij and Russell 2000; Phillips et al. 2010; de Rooij 2017; Yoshida 2019). Unique to germ cells, although some fractions of $A_{\text {undiff }}$ are singly isolated (called $A_{\text {single }}$ or $A_{s}$ ), many others are interconnected with each other via intercellular bridges (ICBs), forming variable lengths of syncytia including $A_{\text {paired }}$ $\left(A_{p r}\right)$ and $A_{\text {aligned }}\left(A_{\text {al }}\right)$ (Russell et al. 1990). A majority of $\mathrm{A}_{\mathrm{al}}$ are composed of $2^{\mathrm{n}}$ cells (i.e., 4, 8, 16 , etc.) as a result of the incomplete cytokinesis in the telophase of mitotic divisions, which connected the mitotic sisters, and the synchronous cell-cycle progression among interconnected cells (Russell et al. 1990), although some compose "odd" numbers of cells other than $2^{\text {n }}$ because of fragmentation of syncytia (described below).

Classically, SSCs were thought to be identical to $A_{s}$ cells (Huckins 1971a,b; Oakberg 1971; de Rooij 1973; Meistrich and van Beek 1993). This paradigm has been challenged by observations that $A_{p r}$ and $A_{a l}$ spermatogonia give rise to $A_{s}$ cells through fragmentation by ICB breakdown, filmed in intravital imaging studies (Nakagawa et al. 2010; Hara et al. 2014), and that $\mathrm{A}_{\mathrm{s}}$ cells are heterogeneous in gene expression, some of which are already destined to differentiation (Nakagawa et al. 2010; Lord and Oatley 2017; Yoshida 2019). Although the identity and behavior of SSCs remain to be fully elucidated, a number of SSC-related signature genes have been identified that can discriminate SSCs among numerous spermatogonia, and define multiple transcriptional and functional states within $\mathrm{A}_{\text {undiff }}$ (for reviews, see Lord and Oatley
2017; La and Hobbs 2019; Yoshida 2019). This view has been reinforced much further by singlecell RNA-seq analyses, which, however, lose the topological information of $\mathrm{A}_{\mathrm{s}}, \mathrm{A}_{\mathrm{pr}}$, or $\mathrm{A}_{\mathrm{al}}$ (Hammoud et al. 2015; Hermann et al. 2015; Chen et al. 2018; Green et al. 2018; La et al. 2018; Suzuki et al. 2019).

Expression of GFR $\alpha 1$ defines a small fraction of $\mathrm{A}_{\text {undiff }}$ harboring SSC functionality, comprised mainly of $A_{s}$ and $A_{p r}$ along with few $A_{a l}$ (Fig. 2B; Meng et al. 2000; Hofmann et al. 2005; Nakagawa et al. 2010; Hara et al. 2014). GFR $\alpha 1^{+}$ cells (largely Nanos $2^{+}$), although self-renewing their population, give rise to GFR $\alpha 1^{-} A_{\text {undiff }}$ (largely, $\mathrm{Ngn}^{+}$, $\mathrm{Miwi}^{+}, \mathrm{RAR}^{+}$); GFR $\alpha 1^{-}$ $A_{\text {undiff }}$ are primed to differentiation and rarely contribute to the self-renewing pool in homeostasis (Fig. 2B; Yoshida et al. 2004; Nakagawa et al. 2007, 2010; Sada et al. 2009; Gely-Pernot et al. 2012; Ikami et al. 2015; Carrieri et al. 2017). GFR $\alpha 1^{-} \mathrm{A}_{\text {undiff }}$ further differentiate to Kit ${ }^{+}$"differentiating spermatogonia" that are committed to differentiate undergoing a defined series of mitotic divisions (through stages called $\mathrm{A}_{1}, \mathrm{~A}_{2}$, $\mathrm{A}_{3}, \mathrm{~A}_{4}$, intermediate $[\mathrm{In}]$, and $\mathrm{B}$ spermatogonia) (Fig. 2A,B; Russell et al. 1990; Schrans-Stassen et al. 1999; Ohbo et al. 2003). GFR $\alpha 1^{+}$cells are further heterogeneous in gene expression, represented by the restricted expressions of genes including Eomes, $P d x 1$, T, or Shisa6 in similar subfractions of the GFR $\alpha 1^{+}$population; the heterogeneity of GFR $\alpha 1^{+}$cells are further represented by variable levels of $I d 4$ expression (Fig. 2C; Helsel et al. 2017; Tokue et al. 2017; Yoshida 2018b, 2019; La and Hobbs 2019; Sharma et al. 2019).

Many intra- and extracellular pathways regulating these self-renewing, primed, and committed states of spermatogonia have been identified at a molecular level (Fig. 2C). Briefly, glial cell-derived neurotrophic factor (GDNF) and fibroblast growth factors (FGFs) play a crucial role to support the self-renewing population expressing GFR $\alpha 1$, a receptor component for GDNF ligand. Wnt/ $\beta$-catenin signal inclines the cells toward a differentiation-primed, GFR $\alpha 1^{-}$state (Takase and Nusse 2016; Chassot et al. 2017; Tokue et al. 2017). Retinoic acid (RA) induces the differentiation of GFR $\alpha 1^{-}$cells to 
S. Yoshida

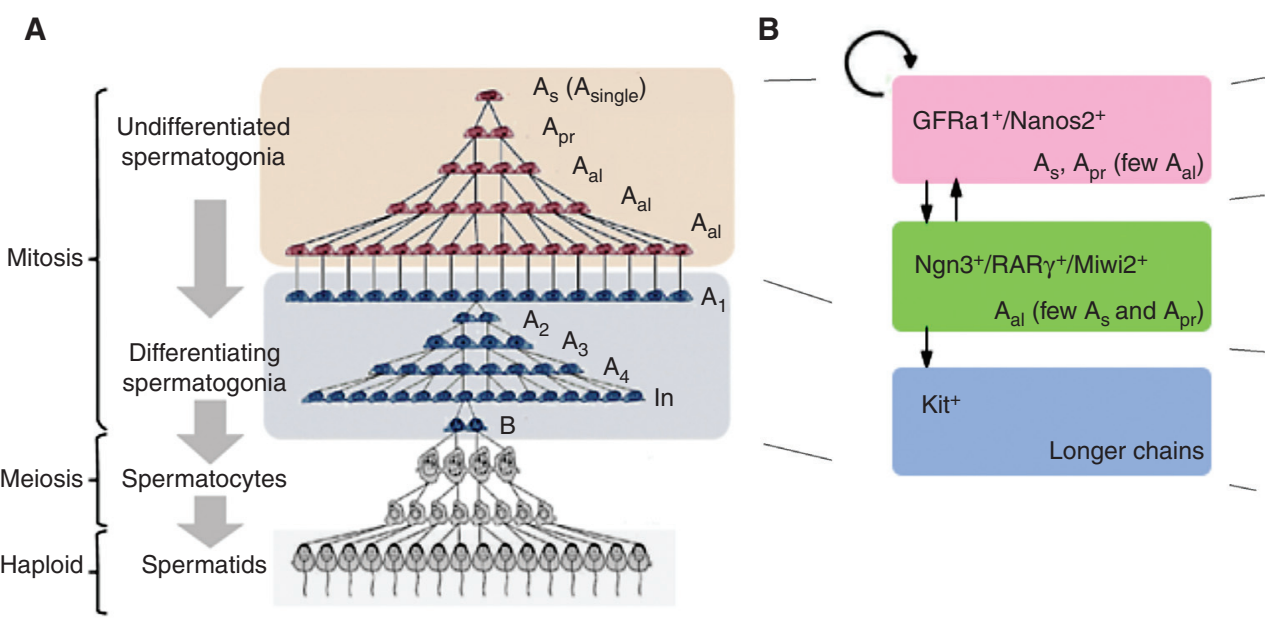

C

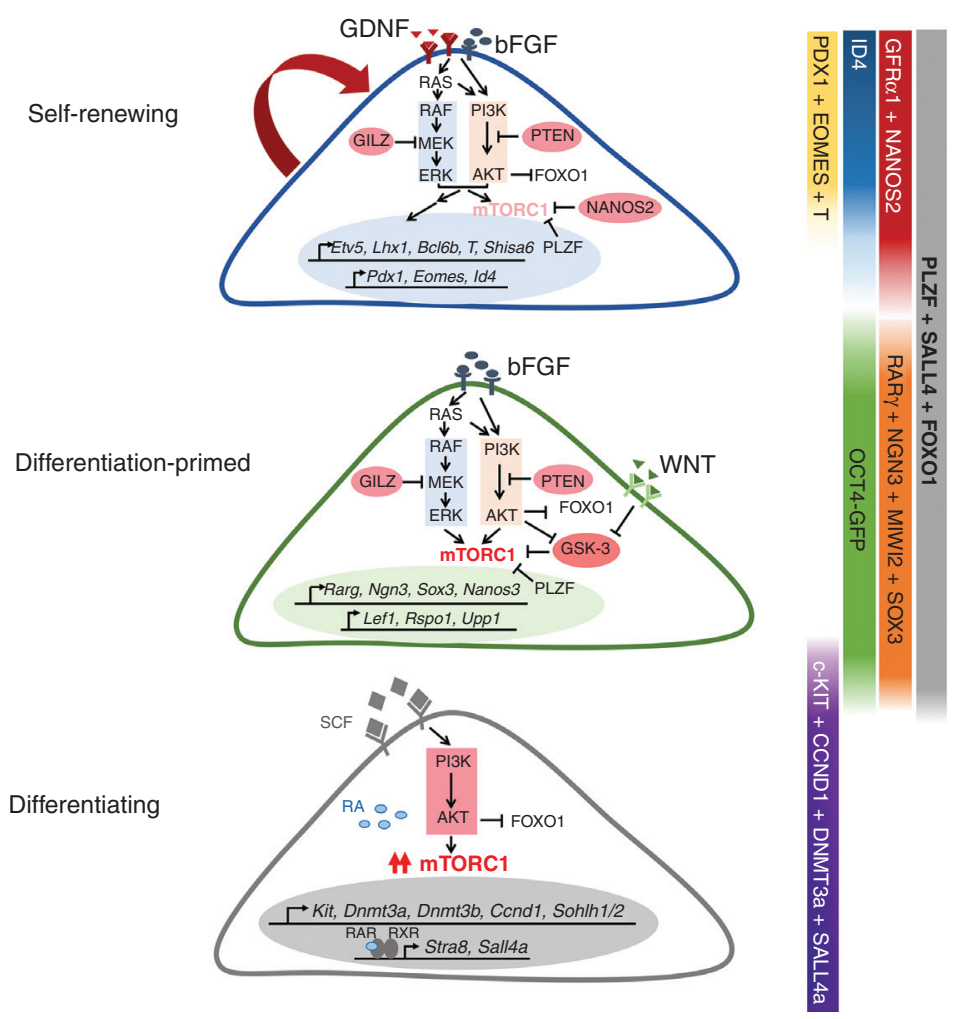

Figure 2. Heterogeneous composition of spermatogonia and their regulation. (A) Spermatogenic cell types observed in the testis of mature mice, showing characteristic syncytial formation. Undifferentiated spermatogonia, responsible for the vast stem cell functionality, are heterogeneous in the number of interconnected cells. $(B) \mathrm{A}$ rough description of the spermatogonial composition based on gene expression. GFR $\alpha 1^{+} / \mathrm{Nanos}^{+}$cells are the primary self-renewing population in homeostasis; $\mathrm{Ngn}^{+} / \mathrm{RAR}^{+} / \mathrm{Miwi}^{+}$cells are differentiation-primed while retaining the stem cell potential; $\mathrm{Kit}^{+}$cells (i.e., differentiating spermatogonia) are essentially committed for differentiation and unidirectionally proceed toward meiosis. (C) Schematic illustrations summarizing the identified molecular pathways regulating the self-renewing, primed, and committed fractions of spermatogonia. ( $A$ adapted from data in Yoshida 2016. C adapted from data in La and Hobbs 2019.) 
become $\mathrm{Kit}^{+}$, mediated by an $\mathrm{RA}$ receptor, $\operatorname{RAR} \gamma$ (Gely-Pernot et al. 2012; Ikami et al. 2015). RAR $\alpha$ also plays auxiliary roles here (Lord et al. 2018). These extracellular signals affect the intracellular machineries, for example, MAPK, PI3K-AKT, $\beta$-catenin, RAR, and mTOR pathways (Fig. 2C). I refer to several reviews for detailed mechanism of SSC regulation (Song and Wilkinson 2014; Yoshida 2018a, 2019; La and Hobbs 2019), while in this review I will focus on the stem cell behavior and regulation within the tissue contexts.

\section{OPEN NICHE MICROENVIRONMENT SUPPORTING SSCs}

SSCs (e.g., GFR $\alpha 1^{+}$spermatogonia) are found scattered within the basal compartment of the seminiferous tubules, intermingled among their differentiating progeny (Fig. 3A,B; Hara et al. 2014; Ikami et al. 2015). Further, they actively move, weaving in between Sertoli cells and other spermatogonia, as filmed using intravital live imaging (Fig. 3C; Hara et al. 2014). These observations are at odds with the traditional view of stem cells being tethered to definitive niche domains, although SSCs in the basal compartment show some degree of preferential localization to an area facing the interstitium and accompanying vasculature (arterioles and venules) (Chiarini-Garcia et al. 2001, 2003; Yoshida et al. 2007b; Hara et al. 2014).

The traditional view is that the ligands supporting the stem cell self-renewal show restricted spatial distribution within the defined niche domain. However, in mouse seminiferous tubules, distribution of GDNF and FGFligands supporting the SSC self-renewal-are not restricted to particular regions. Rather, they are distributed over a wide area where SSCs and their differentiating progenies are both located in an intermingling fashion. Similarly, differentiation-promoting factors (e.g., Wnt and RA) are also suggested to show uniform spatial distribution. Interestingly, GDNF, Wnt, and RA all show temporal fluctuation with different timing in accordance with the seminiferous epithelial cycle, which is a temporally periodic progression of spermatogenesis (Russell et al. 1990;
Sato et al. 2011a; Hogarth et al. 2015; Endo et al. 2017; Tokue et al. 2017; Sharma and Braun 2018; Yoshida 2018a). Therefore, the extracellular microenvironments promoting self-renewal and differentiation are not separated spatially, despite being separated temporally to some extent. Therefore, both SSCs and differentiating cells are quite likely to be exposed to the same extracellular signals (for review, see Yoshida 2018a).

In these tissue contexts, nevertheless, SSCs preserve homeostasis by maintaining their own population, giving rise to differentiating cells to replace the fully differentiated cells that eventually leave the tissue. In particular, despite local fluctuations, the average density of SSCs (i.e., number of SSCs per unit length of tubule) is kept within a small range over the entire length of the tubule, which does not change largely during aging or does not vary between individuals (Fig. 3D,E; Kitadate et al. 2019). Such microenvironments harboring scattered and migrating stem cells are generally referred to as "facultative" or "open" niches with emphasis on their anatomical or functional characteristics, respectively (Fig. 4B), in contrast to traditional "closed" or "definitive" niches, which gather stem cells and regulate their fates locally (Fig. 4A; Morrison and Spradling 2008; Stine and Matunis 2013; Yoshida 2018a).

\section{ADVANTAGES OF MOUSE SPERMATOGENESIS FOR STEM CELL RESEARCH}

Before describing the SSC dynamics observed in the open niche microenvironment of seminiferous tubules, it is worth emphasizing that mouse spermatogenesis has several practical advantages for the study of tissue stem cells (Yoshida 2012). First, as described earlier, based on the uniform structure of seminiferous tubules with constant diameter and virtually infinite length, the function of SSCs can be analyzed in a highly reproducible and quantitative fashion using whole-mount preparation of seminiferous tubules (Huckins and Kopriwa 1969). Second, the progeny of differentiating cells originating from a single SSC, or a clone, remain clustered 
S. Yoshida
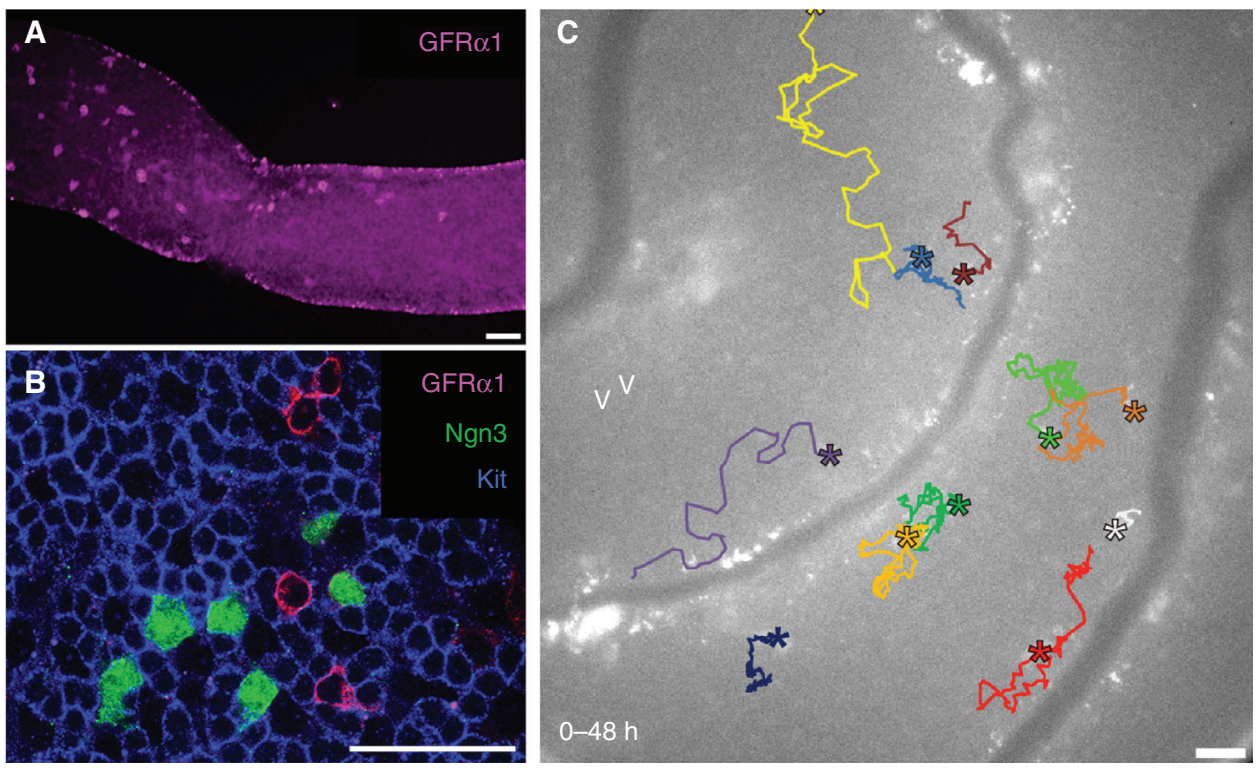

D

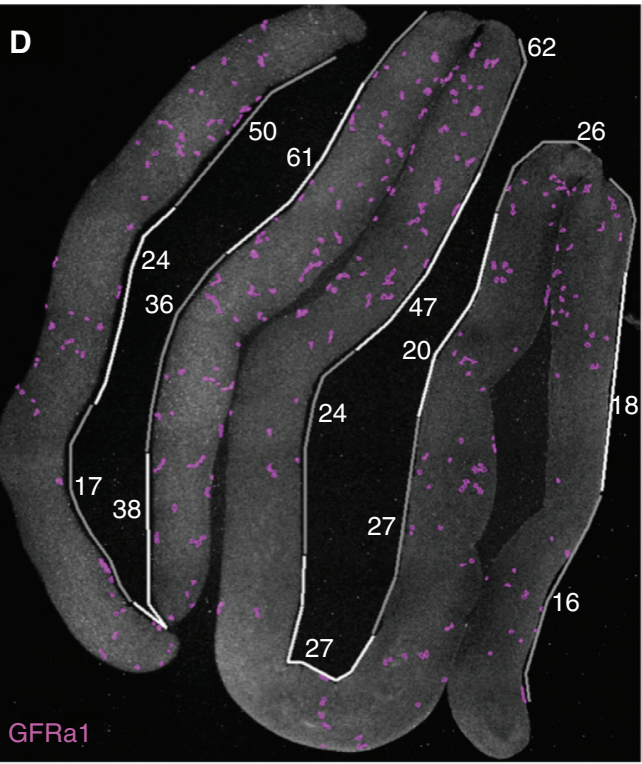

E

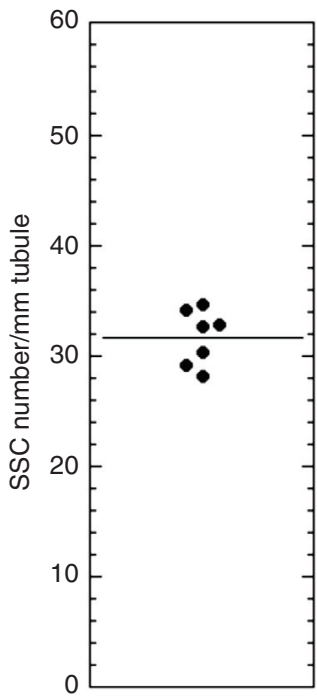

Figure 3. Open niche properties of seminiferous tubules. (A) A whole-mount immufluorescence of a part of seminiferous tubules stained for GFR $\alpha 1$. Note that GFR $\alpha 1^{+}$spermatogenic stem cells (SSCs) are scattered over the basal compartment. (B) A higher magnification view of a part of an adult seminiferous tubles, stained for $\mathrm{GFR} 1^{+}$(magenta), Ngn3-GFP ${ }^{+}$(green), and $\mathrm{Kit}^{+}$(blue) in the basal compartment. Note that these cells are intermingled at a single-cell level. (C) Trajectories of Gfrol-GFP ${ }^{+}$cells in an intact testis recorded for $48 \mathrm{~h}$ by intravital live-imaging. Trajectories are overlain on the first frame in different colors for individual GFR $\alpha 1^{+}$

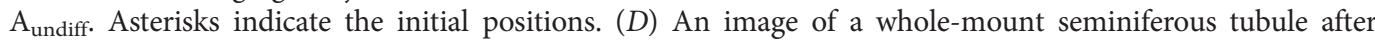
immunofluorescence (IF), in which positions of GFRa $1^{+}$cells are shown in magenta. White and gray lines alongside the tubules indicate 1 -mm-long segments, containing the indicated numbers of GFRa $1^{+}$cells, showing local fluctuation in the SSC density. ( $E$ ) Highly constant average density over continual segments more than 10 $\mathrm{mm}$ long. Horizontal lines indicate the average values. Scale bars, $50 \mu \mathrm{m}$. (Panels $A-E$ from data in Hara et al. 2014, Ikami et al. 2015, and Kitadate et al. 2019.) 

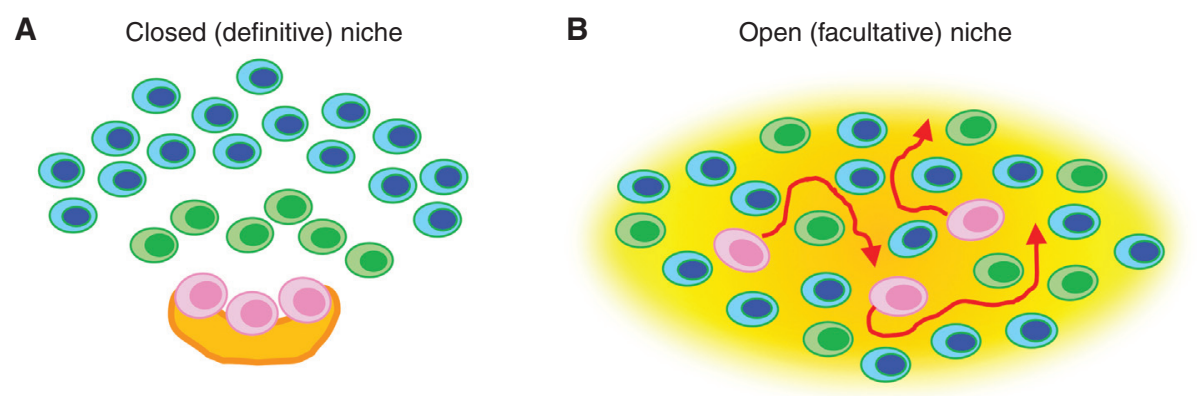

Figure 4. Closed/definitive versus open/facultative niche microenvironments. (A) Closed/definitive niche. Self-renewing cells (magenta) are exclusively located in the anatomically defined niche area where ligand(s) promoting self-renewal is concentrated (orange). Once cells move (or pushed) out of this area, they undergo differentiation, leading to a spatial recapitulation of the order of differentiation steps (from magenta to green and to blue, in this case). Here, cells directionally move slowly away from the niche. (B) An open/facultative niche. Self-renewing cells (magenta) are intermingled with differentiation-primed (green) and committed (blue) progenies, in area where ligand(s) for self-renewal shows a widespread distribution (orange). To maintain such tissue organization under the dynamics of population asymmetry, stem cells must migrate actively to continually interchange their positions.

within the tubules for more than a month until they leave the tissue, enabling precise identification of the clonal cohort (Nakagawa et al.2007). Third, germ cells are dispensable for the basic framework of the tubules and for the survival or health of individuals, thereby enabling an easy assessment of the impact of depletion or other perturbation of SSCs. Fourth, in addition to lineage tracing of pulse-labeled SSCs using inducible Cre-loxP systems (e.g., Nakagawa et al. 2007), other key technologies including SSC transplantation into germ cell-depleted host testes (Brinster and Avarbock 1994; Brinster and Zimmermann 1994), spermatogonia culture that maintains SSC potentials (Kanatsu-Shinohara et al. 2003; Kubota et al. 2004), intravital live-imaging (Yoshida et al. 2007b), and ex vivo seminiferous tubule organ culture (Sato et al. 2011b; Komeya et al. 2016) have been established.

Taking advantages of these properties, studies of mouse SSCs have revealed a number of key dynamics and mechanisms underlying tissue homeostasis and regeneration. In this review, I will describe how the principles/rules/mechanisms that have emerged from the study of SSCs enable a fuller understanding of, and insights to, tissue stem cells in general.

\section{SSC DYNAMICS THAT ARE COMMONLY OBSERVED IN OTHER TISSUES}

How do SSCs support homeostasis (i.e., continual spermatogenesis) and regeneration by controlling the balance between self-renewal and differentiation? The analysis of the fate of individual SSCs in vivo has revealed the population dynamics of SSCs. Some of these are found to be generic for a range of tissue stem cells including those supported by closed niches.

\section{Population Asymmetry}

By pulse-labeling SSCs using tamoxifen-inducible Cre recombinase via a Gfrol-CreER allele, their clonal fate behaviors have been analyzed at a high resolution, including the differentiation status of individual cells within SSC-derived clones (Hara et al. 2014). SSCs follow highly variable fates. Some SSCs give rise to more than one SSC, whereas others produce only differentiating cells. However, their average behavior preserves perfect stem cell dynamics at the population level; that is, they continually selfrenew and produce differentiating cells as schematically shown in Figure 5B (Hara et al. 2014). Reinforcing an earlier study performed at a pop- 
A

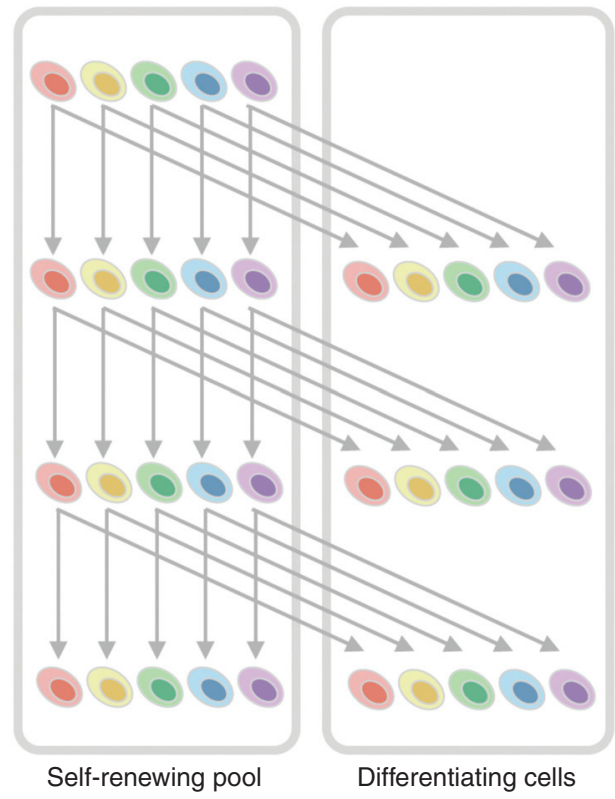

B

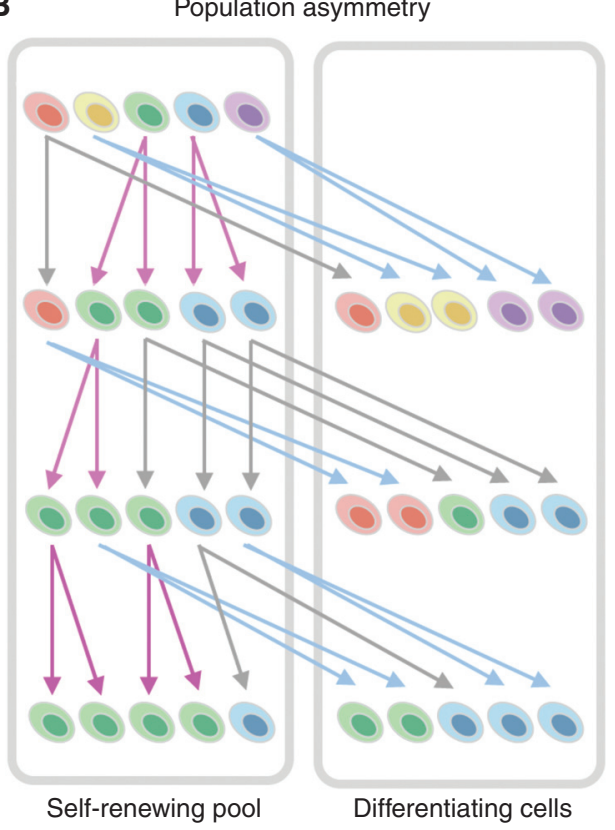

Figure 5. Division asymmetry versus population asymmetry. (A) A diagram of the dynamics of division asymmetry. All the divisions of stem cells (cells in self-renewing compartment) invariantly give rise to the asymmetric outcome with one self-renewing and one differentiating daughter cell. As a result, the clonal repertoire of the selfrenewing pool (indicated by different colors) remains unchanged over time. (B) A diagram of population asymmetry. The balance between self-renewal and differentiation is achieved at the population level so that the number of self-renewing cells is kept constant: Each stem cell division gives rise to variable outcomes, that is, two self-renewing daughters (magenta arrows), two differentiating daughters (blue arrows), or one self-renewing and one differentiating daughter (gray arrows). In this scheme, the stem cells' clonal repertoire drifts over time, becoming dominated by fewer clones, and eventually being dominated by a single clone. (Adapted, with permission, from Yoshida 2019.)

ulation level (Nakagawa et al. 2007), this scheme is consistent with other studies that label different fractions of $\mathrm{A}_{\text {undiff }}$ (e.g., Nanos2 $2^{+}, \mathrm{Bmil}^{+}$, or $\mathrm{Pax}^{+}$) (Sada et al. 2009; Aloisio et al. 2014; Komai et al. 2014). Therefore, the balance between self-renewal and differentiation is achieved at the population level via collective behavior of SSCs (a dynamic called "population asymmetry") rather than at the single-cell level through invariable asymmetric division ("division asymmetry”) (Fig. 5A; Klein and Simons 2011).

\section{Neutral Competition and Clonal Drift}

Strikingly, the highly variable fate of individual SSC clones is found to be predicted precisely by a minimal mathematical model, in which every
SSC is assumed to follow the same probabilistic fate behavior (i.e., to proliferate as SSCs or to differentiate at defined probabilities) (Klein et al. 2010; Hara et al. 2014; Chatzeli and Simons 2020). As a result, during homeostasis, SSCs show "neutral competition" so that the SSC repertoire will be reduced over time, following the dynamics of "neutral drift" (Klein and Simons 2011; Simons and Clevers 2011). Population asymmetry and neutral competition, first described in stem cell systems in interfollicular epidermis (IFE), small intestine epithelium, as well as in mouse spermatogenesis (Clayton et al. 2007; Nakagawa et al. 2007; Doupé et al. 2010; Klein et al. 2010; Lopez-Garcia et al. 2010; Snippert et al. 2010), have been also found in other cycling tissues and recognized as universal rules 
(Klein and Simons 2011; Krieger and Simons 2015; Chatzeli and Simons 2020).

\section{Context Dependence}

Tissue stem cells play roles not only in the maintenance of homeostasis, but also in different contexts such as growth and regeneration (i.e., tissue repair after insult or restoration of tissue functions after transplantation). Contrary to the classical thought that stem cells may be an unequivocally definable entity regardless of context, in mouse spermatogenesis fractions of

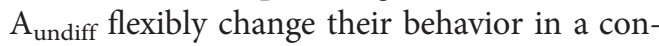
text-dependent manner (Nakagawa et al. 2007; Yoshida et al. 2007a). In particular, the $\mathrm{Ngn}^{+} /$ Miwi2 $^{+}$fraction of $\mathrm{A}_{\text {undiff, }}$ which barely selfrenew but rather differentiate in homeostatic conditions, can convert reversibly to the GFR $\alpha 1^{+}$ state and significantly contribute to the self-renewing pool after insult by a cytotoxic reagent (busulfan) or after transplantation into the seminiferous tubules of host mice (Nakagawa et al. 2007, 2010; Carrieri et al. 2017). Such a flexible change in fate of differentiation-primed cells was first discovered in Drosophila female and male germlines (Brawley and Matunis 2004; Kai and Spradling 2004), followed by mouse spermatogenesis (Nakagawa et al. 2007). Then, such context-dependent reversion of some differentiation-destined-and even terminally differentiated-cells to the self-renewing stem cell pool during regeneration has been found to be a generic feature among many stem cell-supported tissues, in particular a wide range of epithelial tissues, for example, intestinal epithelium, hair follicle and IFE, and lung bronchioalveolar epithelium (reviews include Beumer and Clevers 2016; Santos et al. 2018; de Sousa E Melo and de Sauvage 2019; Das et al. 2020).

\section{Dynamic Heterogeneity}

There is current interest in whether similar state changes also occur during the homeostatic context. By intravital live imaging, GFR $\alpha 1^{+} A_{\text {undiff }}$ were found to interconvert between distinct topological states of $A_{s}$ and syncytia $\left(A_{p r}\right.$ and $A_{a l}$ ) through incomplete division (as a result of in- complete cytokinesis) and syncytial fragmentation (as a result of ICB breakdown) (Hara et al. 2014). This has led to the proposal of "dynamic heterogeneity" in which stem cells maintain their pool through continual interconversion between different states (Krieger and Simons 2015). The observed heterogeneous gene expression within the GFR $\alpha 1^{+}$population (Helsel et al. 2017; La et al. 2018; Yoshida 2019) motivates current investigators to ask whether, and how, SSCs interconvert between multiple transcriptional states during homeostasis. In intestinal crypts, similar state changes of epithelial stem cells during homeostasis is observed to occur in a manner that is closely related to the position within the crypt (Takeda et al. 2011; Buczacki et al. 2013).

\section{SSC DYNAMICS THAT ARE \\ CHARACTERISTIC OF MOUSE SPERMATOGENESIS}

In addition to generic stem cell dynamics, SSC behavior also illustrates the characteristic features of an open niche-supported stem cell system.

\section{Stem Cell Motion}

Among the most striking features of SSCs that distinguish them from many other tissue stem cells is their prominent motion, observed by intravital live-imaging studies (Fig. 3C; Yoshida et al. 2007b; Hara et al. 2014). In the basal compartment of seminiferous tubules, Gfrol-GFP ${ }^{+}$ cells, many of which are singly isolated $\mathrm{A}_{\mathrm{s}}$ cells or $A_{p r}$, continually move around and weave their way between Sertoli cells and differentiating spermatogonia (Yoshida et al. 2007b; Hara et al. 2014). Interestingly, GFR $\alpha 1^{+}$spermatogonia are sparsely scattered and show seemingly random tragedies rather than collective or directional movements, while showing some preference to areas near the interstitium and vasculature. Some GFR $\alpha 1^{+}$SSCs translocate between vasculature-related regions over a distance of $100 \mu \mathrm{m}$ within a day or two without losing their stem cell potential or signature gene expression (e.g., Gfral). Compared to 
GFR $\alpha 1^{+}$cells, $\mathrm{Ngn}^{+}$cells are less motile and tend to stay around the vasculature-proximal region (Yoshida et al. 2007b). On differentiating to $\mathrm{Kit}^{+}$differentiating spermatogonia, they leave these areas to spread evenly over the basal compartment (Yoshida et al. 2007b). Then, when meiosis starts after six rounds of mitotic divisions of differentiating spermatogonia, the cells (spermatocytes) dispatch the basal membrane and translocate vertically into the adluminal compartment. Therefore, SSCs are much more motile than their differentiating progenies.

Compared with the prominent motion of GFR $\alpha 1^{+}$SSCs over long distances in between differentiating cells, the extent of the motion of stem cells in tissues harboring definitive niches is much more limited within the niche domains, including Drosophila testis and ovary (Sheng et al. 2009; Morris and Spradling 2011), mouse intestinal crypt (Ritsma et al. 2014), hair follicle bulge (Rompolas et al. 2012, 2013), and basal layer of IFE (Rompolas et al. 2016), as described later.

\section{Differential Competence to Extracellular Signals}

Within an open niche of seminiferous tubules, fates of SSCs are regulated by a number of extracellular signals (Fig. 2C). As described earlier, GDNF, WNT, and RA show spatially uniform distribution, indicating that SSCs and progenitors are likely to be equally exposed to these factors. However, SSCs show asymmetric fate outcome, for example, self-renewal and differentiation, in a balanced manner. It has turned out that such a different outcome is due to the differential susceptibility to extracellular signals (Yoshida 2018a). First, Shisa6, a cell-intrinsic WNT inhibitor, is expressed in a subfraction of GFR $\alpha 1^{+}$cells, which gain resistance to the differentiation-inducing WNT signal (Tokue et al. 2017). Second, when GFR $\alpha 1^{+}$cells differentiate to GFR $\alpha 1^{-}$, they lose the responsiveness to the self-renewal-promoting ligand, GDNF, as GFR $\alpha 1$ is an essential component of GDNF receptor (Jing et al. 1996). Finally, on losing GFR $\alpha 1$ expression, cells gain the expression of $\mathrm{RAR} \gamma$, and therefore the responsiveness to RA to differentiate to $\mathrm{Kit}^{+}$(Ikami et al. 2015). Thus, the asymmetric fate outcome of SSCs is based on the heterogeneous susceptibilities to widely distributed ligands.

\section{Competition for Widely Distributed Ligands that Promote Self-Renewal}

Within a classic view, stem cell number is kept constant because of limited access to the spatially definitive niche domain, in which the self-renewing factor(s) is present in high concentration (reviews include Watt and Hogan 2000; Fuller and Spradling 2007; Morrison and Spradling 2008; Inaba et al. 2016). In open niches, however, the mechanisms controlling stem cell number (i.e., density) had been unknown. Recently, a mechanism called "mitogen competition" has been proposed to explain the SSC homeostasis in seminiferous tubules (Fig. 6; Kitadate et al. 2019). In this model, motile SSCs effectively compete with each other, without direct cell-cell interactions, by consuming a limited supply of a ligand promoting self-renewal or "mitogen." In particular, SSCs are suggested to compete for FGFs that are secreted from a subset of lymphatic endothelial cells and distributed broadly over the open niche microenvironment (e.g., vasculature-proximal area of the basal compartment) (Fig. 6A). SSCs that have consumed higher amounts of FGFs would express higher levels of FGF target genes and selfrenew with high probability, whereas those that have consumed less FGF would tilt toward differentiation as a result of the expression of differentiation-related genes (Fig. 6B). This theory is primarily based on the linear correlation between SSC density and dose of FGF ligands (Kitadate et al. 2019). It is further supported by the observation that the characteristic oscillating kinetics during the recovery of SSCs after experimental reduction are predicted quantitatively by a simple model based on the mechanism of mitogen competition (Jörg et al. 2019; Kitadate et al. 2019; Chatzeli and Simons 2020). This simple and therefore robust mechanism, which warrants future critical evaluations, would possibly be paradigmatic for stem cell regulation in other open niche-supported tissues. 
A
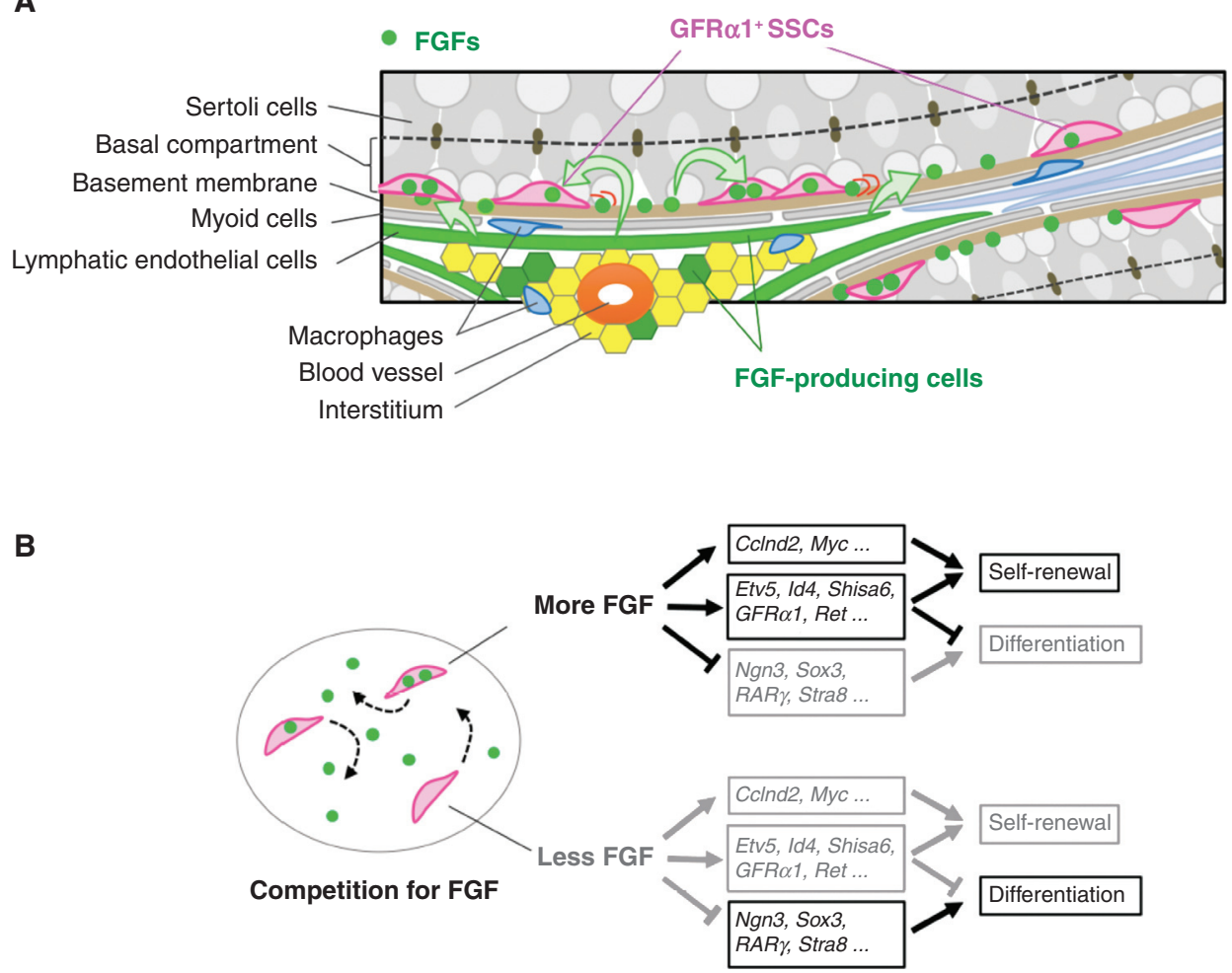

Figure 6. Regulation of spermatogenic stem cells (SSCs) by "mitogen competition" in the basal compartment of seminiferous tubules. (A) Schematic of the open niche microenvironment of the basal compartment of seminiferous tubules, regulating GFRa1 ${ }^{+}$SSCs. A subset of lymphatic endothelial cells and a few interstitial cells (green) fibroblast growth factors (FGFs) (e.g., FGF5, FGF4, FGF8, and possibly others) are produced and secreted to the basal compartment. FGFs, which have an affinity to the basement membrane, are taken up and consumed by motile GFRa1 ${ }^{+}$SSCs and biases their fate behavior in a concentration-dependent manner (see $B$ ). This mechanism self-organizes a density homeostasis of SSCs as well as higher local SSC density near the FGF source. (B) In this scheme, SSCs effectively compete with each other for a limited supply of FGF. SSCs that consume larger amounts of FGF will show higher expression of cell-cycle-promoting and antidifferentiation genes and lower expression of differentiation-promoting genes, tilting their fate toward proliferation without differentiation. SSCs consuming smaller amounts of FGF, on the other hand, will show opposite patterns of target genes, tilting their fate toward differentiation. (Figure reprinted from Kitadate et al. 2019 under the terms of the Creative Commons CC-BY license, which permits unrestricted use, distribution, and reproduction in any medium, provided the original work is properly cited.)

\section{UNITY AND DIVERSITY OF STEM CELL NICHE SYSTEMS}

As described above, the study of the mouse SSCniche system has depicted a number of key features, some of which are generic among tissues, while others emphasize the uniqueness of this open niche-supported system. Here, I would suggest that tissue stem cell systems supported by closed/definitive and open/facultative niches may not be, by nature, as different as they might seem. Rather, tissue stem cells share a number of common properties.

\section{Unity}

Of particular note, the homeostatic stem cell clone dynamics in different tissues (including mouse small intestinal epithelium, IFE, esopha- 
geal epithelium, mammary gland, and spermatogenesis) can be predicted quantitatively by essentially the same class of simple mathematical models that are based on the assumption that stem cells all follow equivalent stochastic (i.e., probabilistic) fate behavior (Klein and Simons 2011; Krieger and Simons 2015; Chatzeli and Simons 2020). This striking finding indicates that stochastic fate behavior (to undergo selfrenewal or differentiation at defined probabilities) may be a generic property of many, if not all, tissue stem cells. In addition, tissue stem cells may flexibly transit between multiple states and support tissue homeostasis and regeneration through interplay with external cues from the niche microenvironments.

\section{Diversity}

Despite the generic principles of fate stochasticity, stem cell niche systems are indeed highly divergent between different tissue types. Such characteristics may, in principle, reflect the different degrees of (1) spatial distribution of ligand(s) supporting the stem cell self-renewal, and (2) the motility of cells in the self-renewing compartment. These key parameters vary in a mutually correlated and coordinated manner in particular tissue contexts, which diverge according to the shape and the size of the tissues, the number of the stem cells, the nature of niche cells and the distribution of stem cell-regulating ligands, and the modes of stem cell niche interactions, as described below for several well-studied tissues and as schematically shown in Figure 7.

\section{A SPECTRUM OF TISSUE STEM CELLS WITH VARYING LIGAND LOCALIZATION AND STEM CELL MOTILITY}

In Figure 7, I will try to show a conceptual spectrum of a number of stem cell-supported tissues based on the considered degrees of ligand localization ( $x$-axis) and stem cell motility ( $y$-axis). Here, the $x$-axis value is based on the extent of spatial distribution of ligands supporting the stem cell self-renewal and the sharpness of their border. The smaller the distributing area is and the sharper the border is, the "more localized" this parameter will be ( plotted leftward), while it will be plotted rightward or "more diffuse" when the ligand is distributed in a widespread and diffusive manner. The $y$-axis value primarily reflects how freely stem cells move over a long distance without losing their stem cell properties. It will be plotted toward the bottom if stem cell motion is restricted, for example, by anchoring to a particular niche structure (e.g., niche cells or extracellular matrixes) or through attachment with the neighboring cells.

These features, in combination, shape the characteristics of stem cell niche interactions in different tissues. Tissues plotted in the bottom left region are more likely supported by a "closed/definitive niche." Conversely, "open/ facultative niche"-supported tissues are found toward the top right. I will give a short overview of a number of tissue stem cell niche systems from this point of view.

\section{Drosophila Ovary and Testis}

Among the tissues investigated in depth, the strongest restrictions with regard to both ligand localization and stem cell motility are observed in Drosophila germ line stem cells (GSCs) (shown in purple and blue, respectively, for female and male in Fig. 7; Yamashita et al. 2005; Fuller and Spradling 2007; Spradling et al. 2011; Nelson et al. 2019). Female and male Drosophila gonads develop specialized niche cells (cap and hub cells, respectively), which secrete ligands for stem cell maintenance (e.g., Dpp and Upd, respectively) that act in close proximity and house a small number of GSCs ( 2-3 and $\sim 6-9$ stem cells per niche, respectively). GSCs and niche cells are attached tightly via adherens junctions, which further constrain the orientation of the mitotic spindles of GSCs (in females, this is mediated by a specialized structure called the spectrosome [Lin et al. 1994]). Furthermore, male GSCs extrude nanotubes into niche cells (Inaba et al. 2015). Accordingly, the niche domain is tightly defined within a single-cell distance from the niche cells, and GSCs undergo asymmetric divisions with high probabilities. However, even in these tissues, stem cell division occasionally gives rise to a symmetric outcome 
Learning from Mouse Sperm Stem Cells

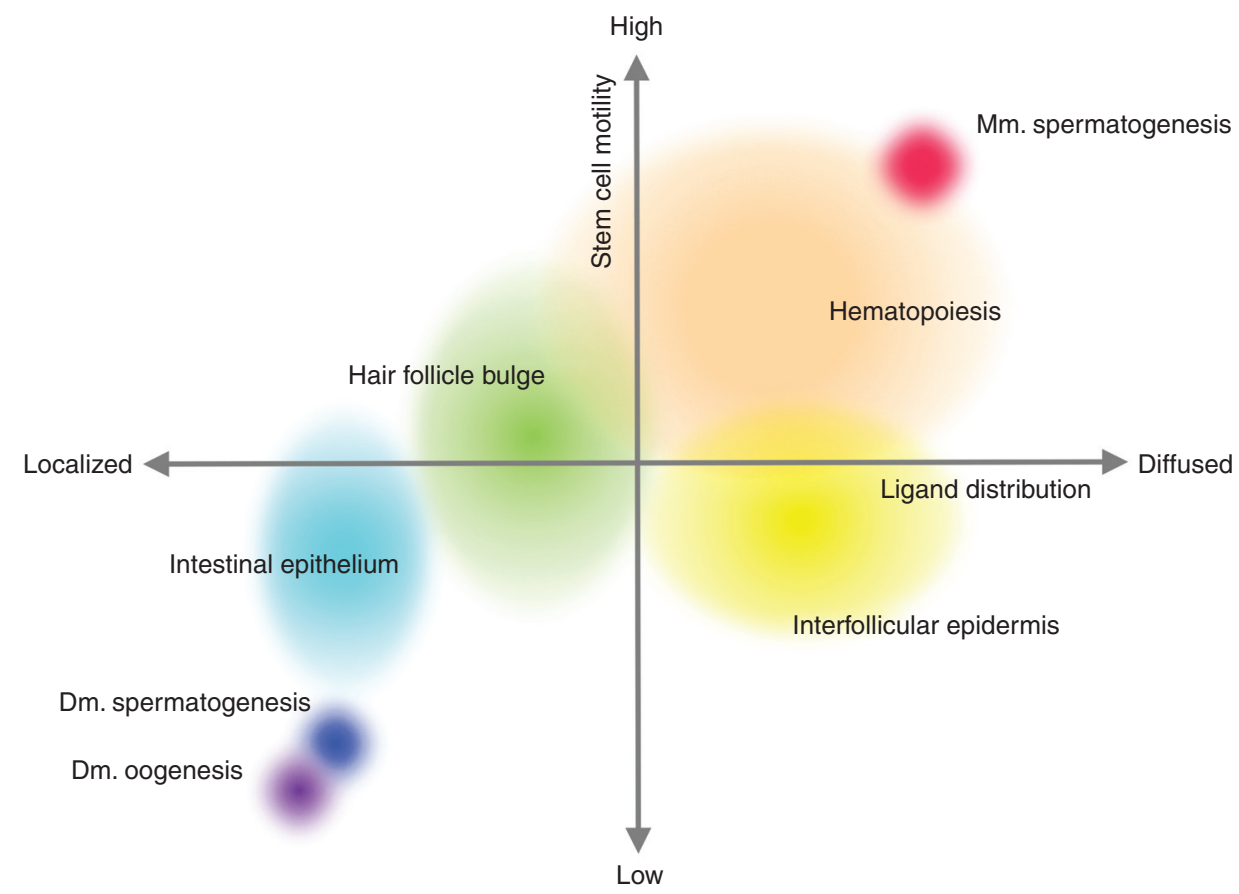

Figure 7. A conceptual presentation of tissue stem cell niche systems. Plots of investigated examples of tissue stem cell niche systems on a hypothetical coordinate plane, based on the considered degrees of ligand localization ( $x$-axis) and stem cell motility ( $y$-axis). Drosophila oogenesis in ovary (purple) and spermatogenesis in testis (blue), mouse intestinal stem cells in the crypt (cyan), mouse hair follicle stem cells in the bulge (green), mouse interfollicular epidermis (yellow), mouse hematopoietic stem cells in bone marrow (orange), and mouse spermatogenesis (red) are shown. See text for details. (Dm.) Drosophila, (Mm.) mouse.

of a pair of differentiating or self-renewing daughter cells, indicating infrequent rearrangement of GSCs in this definitive niche (Sheng and Matunis 2011).

\section{Intestinal Stem Cells in the Crypt}

While considered to be a typical closed/definitive niche, mammalian intestinal crypts show somewhat weaker constraints on intestinal stem cells (ISCs), compared with Drosophila GSCs (cyan in Fig. 7; Clevers 2013; Gehart and Clevers 2019). Typically, $\sim 16$ cells showing a stem cell gene expression signature (including Lgr5) lie intermingled among Paneth cells in the crypt base, which produce Wnts, the major ligands that promote self-renewal acting in a short range (Sato et al. 2011a; Farin et al. 2016). Wnts, as well as R-spondins, are also produced by mesenchymal telocytes, which are also located in proximity to the ISCs across the basement membrane (Santos et al. 2018). No differentiating cells are found within this region (except for Paneth cells and their progenitors), and stem cell properties cannot be maintained outside this region. However, unlike the Drosophila gonads in which stem cell motility is highly restricted, stem cells relocate rather freely and actively within the definitive niche domain, leading to typical dynamics of population asymmetry and rapid clonal drift within a niche (Lopez-Garcia et al. 2010; Snippert et al. 2010; Ritsma et al. 2014; Chatzeli and Simons 2020).

\section{Hair Follicle Bulge}

A more relaxed stem cell niche system is observed in the hair follicle stem cells located in the bulge, which give rise to multiple cell types to comprise the hair and accessory structures (Taylor et al. 
S. Yoshida

2000; Alonso and Fuchs 2003; Hsu et al. 2014; Fujiwara et al. 2018). The hair follicle bulge, albeit its greater spatial extent than the crypt base of intestinal epithelium, may still be better considered as a closed/definitive niche (green in Fig. 7). A single bulge houses hundreds of stem cells, which appear to be heterogeneous depending largely on their position within the bulge region, as suggested from the gene expression and fate behaviors (Rompolas et al. 2012, 2013; Rompolas and Greco 2014; Fujiwara et al. 2018; Rognoni and Watt 2018). The stem cell subsets and the source of the ligands (e.g., Wnts, Tgf $\beta$, and BMPs) show intricate but well-organized spatial heterogeneity within a bulge, as is being realized by combining single-cell transcriptome with tissue immunostaining (Joost et al. 2016). The stem cells are also found to be motile in the bulge to a limited extent (Rompolas et al. 2012).

\section{Interfollicular Epidermis}

In the IFE of mammalian skin, the domain of stem cell localization may not be definable. Indeed, identity of IFE stem cells has not reached full agreement. The basal cells might compose a single self-renewing pool that supports the homeostasis as an entirety, while some degree of functional and transcriptional heterogeneity/ hierarchy has been also evidenced (Jones et al. 2007; Mascré et al. 2012; Sada et al. 2016; Fujiwara et al. 2018; Tabib et al. 2018). Inhomogeneous microenvironment has been implicated in relation to the undulation of basement membrane particularly in humans (Jones et al. 1995; Jensen et al. 1999), which can be recapitulated by artificial culture substrates (Mobasseri et al. 2019). Although these findings suggest the role of mechanical factor to the stem cell-supporting microenvironment, a defined niche domain with localized ligand distribution has not been identified. Rather, this tissue (in particular that of mice showing flattened architecture) would be better considered to be supported by an open niche with virtually infinite spatial extent (yellow in Fig. 7). Here, stem cell clones show population asymmetry and stochastic clonal drift (Clayton et al. 2007; Doupé et al. 2010; Rompolas et al. 2016; Chatzeli and Simons
2020). However, unlike SSCs in seminiferous tubules, the IFE stem cells in the skin develop coherent clones with minimal intermingling. This indicates low motility of IFE stem cells on the basement membrane with rare rearrangements between neighbors. On differentiation to keratinocytes, cells lose the contact with the basement membrane and move vertically.

\section{Hematopoietic Stem Cells in Bone Marrow}

Mammalian bone marrow is considered to provide a typical facultative/open niche microenvironment for hematopoietic stem cells (HSCs) (orange in Fig. 7; Morrison and Spradling 2008; Stine and Matunis 2013). Quite a small number of HSCs, in particular long-term HSCs, are scattered over the marrow, making primary contact with heterogeneous stromal cells secreting a set of ligands (e.g., SCF, CXCL12, thrombopoietin) located perivascularly (Nagasawa et al. 2011; Morrison and Scadden 2014; Crane et al. 2017; Baryawno et al. 2019). Interestingly, however, such microenvironments (i.e., the contact to these niche cells) appear to harbor not only HSCs but also their progenitors, which are present in greater numbers than stem cells. In addition, because of the difficulty in observing the bone marrow and visualizing HSCs live, in situ analyses (in particular the live-imaging studies) of HSCs has been limited to particular situations such as posttransplantation (Lo Celso et al. 2009). Therefore, particular microenvironment supporting HSCs and their behaviors therein warrant investigation based on the success of highly specific visualization of HSCs making use of specific markers, for example, $\alpha$-catulin or Hoxb5 (Acar et al. 2015; Chen et al. 2016). Although HSCs could be tethered to an unidentified definitive region where ligands are concentrated, it may be also possible that the ligands are distributed widely and homeostasis of motile HSCs is achieved by a mechanism similar to SSCs.

\section{Mouse Spermatogenesis}

Finally, mouse spermatogenesis may be plotted on the top right corner of the coordinate plane, 
in the opposite position to the Drosophila gonads (red in Fig. 7). In the basal compartment of seminiferous tubules, in which the ligands (e.g., GDNF and FGFs) are widely supplied, sparsely distributed SSCs show active migration to a much larger extent compared with tissues described above, leading to considerable intermingling between stem cell clones (Nakagawa et al. 2007; Klein et al. 2010; Hara et al. 2014; Kitadate et al. 2019). However, the ligand supply is not perfectly uniform: the FGF-producing cells show a biased localization to extratubular interstitium, in which SSC density is highest (Chiarini-Garcia et al. 2001, 2003; Yoshida et al. 2007b; Kitadate et al. 2019). Therefore, some degree of definitive/closed niche-like property is also evident in mouse testis.

\section{FUTURE QUESTIONS REGARDING SSC DYNAMICS IN SEMINIFEROUS TUBULES}

Based on the findings in mouse spermatogenesis, the unity and diversity of tissue stem cell systems have been discussed, with a special emphasis on the spatial (structural) characteristics in the niche microenvironment and the motility of stem cells therein. In addition, it should be vital to point out the potential importance of temporal changes. Tissue-level homeostasis over large time and spatial scales may be based on local and short-term fluctuations.

There is already evidence that mouse spermatogenesis involves a spatiotemporally coordinated pattern of periodic change, called the "seminiferous epithelial cycle" and "spermatogenic wave” (Russell et al. 1990; Yoshida 2019). Within a short segment of a tubule, generation of differentiating spermatogonia from the $\mathrm{A}_{\text {undiff }}$ compartment and subsequent differentiation steps occur synchronously in a temporally periodic manner, showing an interval of 8.6 days in the case of mice (cycle) (Leblond and Clermont 1952; Oakberg 1956). Furthermore, the phase of this "cycle" is recapitulated spatially along the length of the tubule, resulting in a traveling wave-like spatiotemporal orchestration (wave) (Perey et al. 1961).

Historically, cycle and wave have provided invaluable clues to researches on the fate of SSCs based on static information. The data were obtained from fixed tissues (including S-phase labeling) when cell-fate tracing within a tissue (e.g., live imaging or lineage tracing) was not possible (Huckins 1971b; Meistrich and van Beek 1993). Application of recent analytical techniques will throw light on the SSC dynamics within a temporally fluctuating niche microenvironment. Indeed, production of GDNF in Sertoli cells oscillates in a temporally periodic manner in accordance with the cycle (Sato et al. 2011a; Tokue et al. 2017; Sharma and Braun 2018). Further, hair follicle bulge stem cells change their properties periodically to promote the hair cycle (Rompolas and Greco 2014; Lay et al. 2016; Wang et al. 2016; Adam et al. 2018). Similar temporal fluctuation could be involved in other tissues, although it might be hidden by the lack of clear local synchronization or spatial pattern. In any case, the issue of time dependence will enhance our understanding of tissue stem cells.

\section{CONCLUDING REMARKS}

In this review, I have summarized the contributions made by the study of mouse spermatogenesis to a general understanding of tissue stem cell niche systems. Based on the biological and technical advantages of the system, mouse spermatogenesis will continue to provide important new insights into the properties of stem cells and their regulation by the niche.

\section{ACKNOWLEDGMENTS}

I am grateful to all our laboratory members and colleagues for the past and ongoing exciting collaborations and discussions. Fruitful comments from Ben Simons and Hironobu Fujiwara on this manuscript are really appreciated. Researches conducted in our laboratory and described in this article have been supported in part by the Grant-in-Aid for Scientific Research (KAKENHI) program from the Ministry of Education, Culture, Sports, Science and Technology (MEXT) and Japan Society for the Promotion of Science (JSPS), the PRESTO program from Japan Science and Technology Agency (JST), 
S. Yoshida

and the AMED-CREST program from the Japan Agency for Medical Research and Development (AMED). The author has no conflict of interests to declare.

\section{REFERENCES}

${ }^{*}$ Reference is also in this collection.

Acar M, Kocherlakota KS, Murphy MM, Peyer JG, Oguro H, Inra CN, Jaiyeola C, Zhao Z, Luby-Phelps K, Morrison SJ. 2015. Deep imaging of bone marrow shows non-dividing stem cells are mainly perisinusoidal. Nature 526: 126130. doi:10.1038/nature 15250

Adam RC, Yang H, Ge Y, Lien WH, Wang P, Zhao Y, Polak L, Levorse J, Baksh SC, Zheng D, et al. 2018. Temporal layering of signaling effectors drives chromatin remodeling during hair follicle stem cell lineage progression. Cell Stem Cell 22: 398-413.e7. doi:10.1016/j.stem .2017.12.004

Aloisio GM, Nakada Y, Saatcioglu HD, Peña CG, Baker MD Tarnawa ED, Mukherjee J, Manjunath H, Bugde A, Sengupta AL, et al. 2014. PAX7 expression defines germline stem cells in the adult testis. JClin Invest 124: 3929-3944. doi:10.1172/JCI75943

Alonso L, Fuchs E. 2003. Stem cells of the skin epithelium. Proc Natl Acad Sci 100: 11830-11835. doi:10.1073/pnas .1734203100

Baryawno N, Przybylski D, Kowalczyk MS, Kfoury Y, Severe N, Gustafsson K, Kokkaliaris KD, Mercier F, Tabaka M, Hofree M, et al. 2019. A cellular taxonomy of the bone marrow stroma in homeostasis and leukemia. Cell 177: 1915-1932.e16. doi:10.1016/j.cell.2019.04.040

Beumer J, Clevers H. 2016. Regulation and plasticity of intestinal stem cells during homeostasis and regeneration. Development 143: 3639-3649. doi:10.1242/dev.133132

Brawley C, Matunis E. 2004. Regeneration of male germline stem cells by spermatogonial dedifferentiation in vivo. Science 304: 1331-1334. doi:10.1126/science.1097676

Brinster RL, Avarbock MR. 1994. Germline transmission of donor haplotype following spermatogonial transplantation. Proc Natl Acad Sci 91: 11303-11307. doi:10.1073/ pnas.91.24.11303

Brinster RL, Zimmermann JW. 1994. Spermatogenesis following male germ-cell transplantation. Proc Natl Acad Sci 91: 11298-11302. doi:10.1073/pnas.91.24.11298

Buczacki SJ, Zecchini HI, Nicholson AM, Russell R, Vermeulen L, Kemp R, Winton DJ. 2013. Intestinal labelretaining cells are secretory precursors expressing Lgr5. Nature 495: 65-69. doi:10.1038/nature11965

Carrieri C, Comazzetto S, Grover A, Morgan M, Buness A, Nerlov C, O'Carroll D. 2017. A transit-amplifying population underpins the efficient regenerative capacity of the testis. J Exp Med 214: 1631-1641. doi:10.1084/jem .20161371

Chassot AA, Le Rolle M, Jourden M, Taketo MM, Ghyselinck NB, Chaboissier MC. 2017. Constitutive WNT/ CTNNB1 activation triggers spermatogonial stem cell proliferation and germ cell depletion. Dev Biol 426: 1727. doi:10.1016/j.ydbio.2017.04.010
* Chatzeli L, Simons BD. 2020. Tracing the dynamics of stem cell fate. Cold Spring Harb Perspect Biol doi:10.1101/ cshperspect.a036202

Chen JY, Miyanishi M, Wang SK, Yamazaki S, Sinha R, Kao KS, Seita J, Sahoo D, Nakauchi H, Weissman IL. 2016. Hoxb5 marks long-term haematopoietic stem cells and reveals a homogenous perivascular niche. Nature 530: 223-227. doi:10.1038/nature16943

Chen Y, Zheng Y, Gao Y, Lin Z, Yang S, Wang T, Wang Q, Xie N, Hua R, Liu M, et al. 2018. Single-cell RNA-Seq uncovers dynamic processes and critical regulators in mouse spermatogenesis. Cell Res 28: 879-896. doi:10 .1038/s41422-018-0074-y

Chiarini-Garcia H, Hornick JR, Griswold MD, Russell LD. 2001. Distribution of type A spermatogonia in the mouse is not random. Biol Reprod 65: 1179-1185. doi:10.1095/ biolreprod65.4.1179

Chiarini-Garcia H, Raymer AM, Russell LD. 2003. Nonrandom distribution of spermatogonia in rats: evidence of niches in the seminiferous tubules. Reproduction 126: 669-680. doi:10.1530/rep.0.1260669

Clayton E, Doupé DP, Klein AM, Winton DJ, Simons BD, Jones PH. 2007. A single type of progenitor cell maintains normal epidermis. Nature 446: 185-189. doi:10.1038/na ture 05574

Clevers H. 2013. The intestinal crypt, a prototype stem cell compartment. Cell 154: 274-284. doi:10.1016/j.cell.2013 .07 .004

Crane GM, Jeffery E, Morrison SJ. 2017. Adult haematopoietic stem cell niches. Nat Rev Immunol 17: 573-590. doi:10.1038/nri.2017.53

Das D, Fletcher RB, Ngai J. 2020. Cellular mechanisms of epithelial stem cell self-renewal and differentiation during homeostasis and repair. Wiley Interdiscip Rev Dev Biol 9: e361.

de Rooij DG. 1973. Spermatogonial stem cell renewal in the mouse. I: Normal situation. Cell Tissue Kinet 6: 281-287.

de Rooij DG. 2017. The nature and dynamics of spermatogonial stem cells. Development 144: 3022-3030. doi:10 $.1242 /$ dev.146571

de Rooij DG, Russell LD. 2000. All you wanted to know about spermatogonia but were afraid to ask. J Androl 21: 776-798

de Sousa E Melo F, de Sauvage FJ. 2019. Cellular plasticity in intestinal homeostasis and disease. Cell Stem Cell 24: 5464. doi:10.1016/j.stem.2018.11.019

Doupé DP, Klein AM, Simons BD, Jones PH. 2010. The ordered architecture of murine ear epidermis is maintained by progenitor cells with random fate. Dev Cell 18: 317-323. doi:10.1016/j.devcel.2009.12.016

Endo T, Freinkman E, de Rooij DG, Page DC. 2017. Periodic production of retinoic acid by meiotic and somatic cells coordinates four transitions in mouse spermatogenesis. Proc Natl Acad Sci 114: E10132-E10141. doi:10.1073/ pnas. 1710837114

Farin HF, Jordens I, Mosa MH, Basak O, Korving J, Tauriello DV, de Punder K, Angers S, Peters PJ, Maurice MM, et al. 2016. Visualization of a short-range Wnt gradient in the intestinal stem-cell niche. Nature 530: 340-343. doi:10 $.1038 /$ nature 16937 
Fujiwara H, Tsutsui K, Morita R. 2018. Multi-tasking epidermal stem cells: beyond epidermal maintenance. Dev Growth Differ 60: 531-541. doi:10.1111/dgd.12577

Fuller MT, Spradling AC. 2007. Male and female Drosophila germline stem cells: two versions of immortality. Science 316: 402-404. doi:10.1126/science.1140861

Gehart H, Clevers H. 2019. Tales from the crypt: new insights into intestinal stem cells. Nat Rev Gastroenterol Hepatol 16: 19-34. doi:10.1038/s41575-018-0081-y

Gely-Pernot A, Raverdeau M, Célébi C, Dennefeld C, Feret B, Klopfenstein M, Yoshida S, Ghyselinck NB, Mark M 2012. Spermatogonia differentiation requires retinoic acid receptor $\gamma$. Endocrinology 153: 438-449. doi:10.1210/en 2011-1102

Green CD, Ma Q, Manske GL, Shami AN, Zheng X, Marini S, Moritz L, Sultan C, Gurczynski SJ, Moore BB, et al. 2018. A comprehensive roadmap of murine spermatogenesis defined by single-cell RNA-Seq. Dev Cell 46: 651-667.e10. doi:10.1016/j.devcel.2018.07.025

Hammoud SS, Low DH, Yi C, Lee CL, Oatley JM, Payne CJ, Carrell DT, Guccione E, Cairns BR. 2015. Transcription and imprinting dynamics in developing postnatal male germline stem cells. Genes Dev 29: 2312-2324. doi:10 $.1101 /$ gad.261925.115

Hara K, Nakagawa T, Enomoto H, Suzuki M, Yamamoto M, Simons BD, Yoshida S. 2014. Mouse spermatogenic stem cells continually interconvert between equipotent singly isolated and syncytial states. Cell Stem Cell 14: 658-672. doi:10.1016/j.stem.2014.01.019

Helsel AR, Yang QE, Oatley MJ, Lord T, Sablitzky F, Oatley JM. 2017. ID4 levels dictate the stem cell state in mouse spermatogonia. Development 144: 624-634. doi:10.1242/ dev.146928

Hermann BP, Mutoji KN, Velte EK, Ko D, Oatley JM, Geyer CB, McCarrey JR. 2015. Transcriptional and translational heterogeneity among neonatal mouse spermatogonia. Biol Reprod 92: 54. doi:10.1095/biolreprod.114.125757

Hofmann MC, Braydich-Stolle L, Dym M. 2005. Isolation of male germ-line stem cells; influence of GDNF. Dev Biol 279: 114-124. doi:10.1016/j.ydbio.2004.12.006

Hogarth CA, Arnold S, Kent T, Mitchell D, Isoherranen N, Griswold MD. 2015. Processive pulses of retinoic acid propel asynchronous and continuous murine sperm production. Biol Reprod 92: 37. doi:10.1095/biolreprod.114 .126326

Hsu YC, Li L, Fuchs E. 2014. Emerging interactions between skin stem cells and their niches. Nat Med 20: 847-856. doi: $10.1038 / \mathrm{nm} .3643$

Huckins C. 1971a. The spermatogonial stem cell population in adult rats. I: Their morphology, proliferation and maturation. Anat Rec 169: 533-557.

Huckins C. 1971b. The spermatogonial stem cell population in adult rats. II: A radioautographic analysis of their cell cycle properties. Cell Tissue Kinet 4: 313-334.

Huckins C, Kopriwa BM. 1969. A technique for the radioautography of germ cells in whole mounts of seminiferous tubules. J Histochem Cytochem 17: 848-851. doi:10.1177/ 17.12 .848

Ikami K, Tokue M, Sugimoto R, Noda C, Kobayashi S, Hara K, Yoshida S. 2015. Hierarchical differentiation competence in response to retinoic acid ensures stem cell main- tenance during mouse spermatogenesis. Development 142: 1582-1592. doi:10.1242/dev.118695

Inaba M, Buszczak M, Yamashita YM. 2015. Nanotubes mediate niche-stem-cell signalling in the Drosophila testis. Nature 523: 329-332. doi:10.1038/nature14602

Inaba M, Yamashita YM, Buszczak M. 2016. Keeping stem cells under control: new insights into the mechanisms that limit niche-stem cell signaling within the reproductive system. Mol Reprod Dev 83: 675-683. doi:10.1002/mrd .22682

Jensen UB, Lowell S, Watt FM. 1999. The spatial relationship between stem cells and their progeny in the basal layer of human epidermis: a new view based on whole-mount labelling and lineage analysis. Development 126: 24092418 .

Jing S, Wen D, Yu Y, Holst PL, Luo Y, Fang M, Tamir R, Antonio L, Hu Z, Cupples R, et al. 1996. GDNF-induced activation of the ret protein tyrosine kinase is mediated by GDNFR- $\alpha$, a novel receptor for GDNF. Cell 85: 1113 1124. doi:10.1016/S0092-8674(00)81311-2

Jones PH, Harper S, Watt FM. 1995. Stem cell patterning and fate in human epidermis. Cell 80: 83-93. doi:10.1016/ 0092-8674(95)90453-0

Jones PH, Simons BD, Watt FM. 2007. Sic transit gloria: farewell to the epidermal transit amplifying cell? Cell Stem Cell 1: 371-381. doi:10.1016/j.stem.2007.09.014

Joost S, Zeisel A, Jacob T, Sun X, La Manno G, Lönnerberg P, Linnarsson S, Kasper M. 2016. Single-cell transcriptomics reveals that differentiation and spatial signatures shape epidermal and hair follicle heterogeneity. Cell Syst 3: 221-237.e9. doi:10.1016/j.cels.2016.08.010

Jörg DJ, Kitadate Y, Yoshida S, Simons BD. 2019. Competition for stem cell fate determinants as a mechanism for tissue homeostasis. arXiv 190103903.

Kai T, Spradling A. 2004. Differentiating germ cells can revert into functional stem cells in Drosophila melanogaster ovaries. Nature 428: 564-569. doi:10.1038/nature02436

Kanatsu-Shinohara M, Ogonuki N, Inoue K, Miki H, Ogura A, Toyokuni S, Shinohara T. 2003. Long-term proliferation in culture and germline transmission of mouse male germline stem cells. Biol Reprod 69: 612-616. doi:10 .1095/biolreprod.103.017012

Kitadate Y, Jörg DJ, Tokue M, Maruyama A, Ichikawa R, Tsuchiya S, Segi-Nishida E, Nakagawa T, Uchida A, Kimura-Yoshida C, et al. 2019. Competition for mitogens regulates spermatogenic stem cell homeostasis in an open niche. Cell Stem Cell 24: 79-92.e6. doi:10.1016/j.stem 2018.11.013

Klein AM, Simons BD. 2011. Universal patterns of stem cell fate in cycling adult tissues. Development 138: 3103-3111. doi: $10.1242 /$ dev.060103

Klein AM, Nakagawa T, Ichikawa R, Yoshida S, Simons BD. 2010. Mouse germ line stem cells undergo rapid and stochastic turnover. Cell Stem Cell 7: 214-224. doi:10.1016/j stem.2010.05.017

Komai Y, Tanaka T, Tokuyama Y, Yanai H, Ohe S, Omachi T, Atsumi N, Yoshida N, Kumano K, Hisha H, et al. 2014 Bmil expression in long-term germ stem cells. Sci Rep 4: 6175. doi:10.1038/srep06175

Komeya M, Kimura H, Nakamura H, Yokonishi T, Sato T, Kojima K, Hayashi K, Katagiri K, Yamanaka H, Sanjo H, 
S. Yoshida

et al. 2016. Long-term ex vivo maintenance of testis tissues producing fertile sperm in a microfluidic device. Sci Rep 6: 21472. doi:10.1038/srep21472

Krieger T, Simons BD. 2015. Dynamic stem cell heterogeneity. Development 142: 1396-1406. doi:10.1242/dev.10 1063

Kubota H, Avarbock MR, Brinster RL. 2004. Growth factors essential for self-renewal and expansion of mouse spermatogonial stem cells. Proc Natl Acad Sci 101: 1648916494. doi:10.1073/pnas.0407063101

La HM, Hobbs RM. 2019. Mechanisms regulating mammalian spermatogenesis and fertility recovery following germ cell depletion. Cell Mol Life Sci 76: 4071-4102. doi:10.1007/s00018-019-03201-6

La HM, Mäkelä JA, Chan AL, Rossello FJ, Nefzger CM, Legrand JMD, De Seram M, Polo JM, Hobbs RM. 2018. Identification of dynamic undifferentiated cell states within the male germline. Nat Commun 9: 2819. doi:10 .1038/s41467-018-04827-z

Lay K, Kume T, Fuchs E. 2016. FOXC1 maintains the hair follicle stem cell niche and governs stem cell quiescence to preserve long-term tissue-regenerating potential. Proc Natl Acad Sci 113: E1506-E1515. doi:10.1073/pnas 1601569113

Leblond CP, Clermont Y. 1952. Definition of the stages of the cycle of the seminiferous epithelium in the rat. Ann NY Acad Sci 55: 548-573. doi:10.1111/j.1749-6632.1952 .tb26576.x

Lin H, Yue L, Spradling AC. 1994. The Drosophila fusome, a germline-specific organelle, contains membrane skeletal proteins and functions in cyst formation. Development 120: 947-956.

Lo Celso L, Fleming HE, Wu JW, Zhao CX, Miake-Lye S, Fujisaki J, Côté D, Rowe DW, Lin CP, Scadden DT. 2009. Live-animal tracking of individual haematopoietic stem/ progenitor cells in their niche. Nature 457: 92-96. doi:10 $.1038 /$ nature 07434

Lopez-Garcia C, Klein AM, Simons BD, Winton DJ. 2010. Intestinal stem cell replacement follows a pattern of neutral drift. Science 330: 822-825. doi:10.1126/science .1196236

Lord T, Oatley JM. 2017. A revised Asingle model to explain stem cell dynamics in the mouse male germline. Reproduction 154: R55-R64. doi:10.1530/REP-17-0034

Lord T, Oatley MJ, Oatley JM. 2018. Testicular architecture is critical for mediation of retinoic acid responsiveness by undifferentiated spermatogonial subtypes in the mouse. Stem Cell Reports 10: 538-552. doi:10.1016/j.stemcr.2018 .01 .003

Mascré G, Dekoninck S, Drogat B, Youssef KK, Brohée S, Sotiropoulou PA, Simons BD, Blanpain C. 2012. Distinct contribution of stem and progenitor cells to epidermal maintenance. Nature 489: 257-262. doi:10.1038/na ture11393

Meistrich ML, van Beek ME. 1993. Spermatogonial stem cells. In Cell and molecular biology of the testis (ed. Desjardins C, Ewing LL), pp. 266-295. Oxford University Press, New York.

Meng X, Lindahl M, Hyvönen ME, Parvinen M, de Rooij DG, Hess MW, Raatikainen-Ahokas A, Sainio K, Rauvala H, Lakso M, et al. 2000. Regulation of cell fate decision of undifferentiated spermatogonia by GDNF. Science 287: 1489-1493. doi:10.1126/science.287.5457.1489

Mobasseri SA, Zijl S, Salameti V, Walko G, Stannard A, Garcia-Manyes S, Watt FM. 2019. Patterning of human epidermal stem cells on undulating elastomer substrates reflects differences in cell stiffness. Acta Biomater 87: 256-264. doi:10.1016/j.actbio.2019.01.063

Morris LX, Spradling AC. 2011. Long-term live imaging provides new insight into stem cell regulation and germline-soma coordination in the Drosophila ovary. Development 138: 2207-2215. doi:10.1242/dev.065508

Morrison SJ, Scadden DT. 2014. The bone marrow niche for haematopoietic stem cells. Nature 505: 327-334. doi:10 $.1038 /$ nature 12984

Morrison SJ, Spradling AC. 2008. Stem cells and niches: mechanisms that promote stem cell maintenance throughout life. Cell 132: 598-611. doi:10.1016/j.cell .2008 .01 .038

Nagasawa T, Omatsu Y, Sugiyama T. 2011. Control of hematopoietic stem cells by the bone marrow stromal niche: the role of reticular cells. Trends Immunol 32: 315-320. doi:10.1016/j.it.2011.03.009

Nakagawa T, Nabeshima Y, Yoshida S. 2007. Functional identification of the actual and potential stem cell compartments in mouse spermatogenesis. Dev Cell 12: 195206. doi:10.1016/j.devcel.2007.01.002

Nakagawa T, Sharma M, Nabeshima Y, Braun RE, Yoshida S. 2010. Functional hierarchy and reversibility within the murine spermatogenic stem cell compartment. Science 328: 62-67. doi:10.1126/science. 1182868

Nelson JO, Chen C, Yamashita YM. 2019. Germline stem cell homeostasis. Curr Top Dev Biol 135: 203-244. doi:10 $.1016 /$ bs.ctdb.2019.04.006

Oakberg EF. 1956. Duration of spermatogenesis in the mouse and timing of stages of the cycle of the seminiferous epithelium. Am J Anat 99: 507-516. doi:10.1002/aja .1000990307

Oakberg EF. 1971. Spermatogonial stem-cell renewal in the mouse. Anat Rec 169: 515-531. doi:10.1002/ar .1091690305

Ohbo K, Yoshida S, Ohmura M, Ohneda O, Ogawa T, Tsuchiya H, Kuwana T, Kehler J, Abe K, Schöler HR, et al. 2003. Identification and characterization of stem cells in prepubertal spermatogenesis in mice. Dev Biol 258: 209225. doi:10.1016/S0012-1606(03)00111-8

Perey B, Clermont Y, Leblond CP. 1961. The wave of the seminiferous epithelium in the rat. Dev Dyn 108: 47-77.

Phillips BT, Gassei K, Orwig KE. 2010. Spermatogonial stem cell regulation and spermatogenesis. Philos Trans $R$ Soc Lond B Biol Sci 365: 1663-1678. doi:10.1098/rstb.2010 .0026

Ritsma L, Ellenbroek SIJ, Zomer A, Snippert HJ, de Sauvage FJ, Simons BD, Clevers H, van Rheenen J. 2014. Intestinal crypt homeostasis revealed at single-stem-cell level by in vivo live imaging. Nature 507: 362-365. doi:10.1038/na ture12972

Rognoni E, Watt FM. 2018. Skin cell heterogeneity in development, wound healing, and cancer. Trends Cell Biol 28: 709-722. doi:10.1016/j.tcb.2018.05.002 
Rompolas P, Greco V. 2014. Stem cell dynamics in the hair follicle niche. Semin Cell Dev Biol 25-26: 34-42. doi:10 $.1016 /$ j.semcdb.2013.12.005

Rompolas P, Deschene ER, Zito G, Gonzalez DG, Saotome I, Haberman AM, Greco V. 2012. Live imaging of stem cell and progeny behaviour in physiological hair-follicle regeneration. Nature 487: 496-499. doi:10.1038/na ture11218

Rompolas P, Mesa KR, Greco V. 2013. Spatial organization within a niche as a determinant of stem-cell fate. Nature 502: 513-518. doi:10.1038/nature 12602

Rompolas P, Mesa KR, Kawaguchi K, Park S, Gonzalez D, Brown S, Boucher J, Klein AM, Greco V. 2016. Spatiotemporal coordination of stem cell commitment during epidermal homeostasis. Science 352: 1471-1474. doi:10 $.1126 /$ science.aaf7012

Russell L, Ettlin R, Sinha Hikim A, Clegg E. 1990. Histological and histopathological evaluation of the testis. Cache River, Clearwater, FL.

Sada A, Suzuki A, Suzuki H, Saga Y. 2009. The RNA-binding protein NANOS2 is required to maintain murine spermatogonial stem cells. Science 325: 1394-1398. doi:10 $.1126 /$ science. 1172645

Sada A, Jacob F, Leung E, Wang S, White BS, Shalloway D, Tumbar T. 2016. Defining the cellular lineage hierarchy in the interfollicular epidermis of adult skin. Nat Cell Biol 18: 619-631. doi:10.1038/ncb3359

Santos AJM, Lo YH, Mah AT, Kuo CJ. 2018. The intestinal stem cell niche: homeostasis and adaptations. Trends Cell Biol 28: 1062-1078. doi:10.1016/j.tcb.2018.08 .001

Sato T, Aiyama Y, Ishii-Inagaki M, Hara K, Tsunekawa N, Harikae K, Uemura-Kamata M, Shinomura M, Zhu XB, Maeda S, et al. 2011a. Cyclical and patch-like GDNF distribution along the basal surface of Sertoli cells in mouse and hamster testes. PLoS ONE 6: e28367. doi:10.1371/ journal.pone.0028367

Sato T, Katagiri K, Gohbara A, Inoue K, Ogonuki N, Ogura A, Kubota Y, Ogawa T. 2011b. In vitro production of functional sperm in cultured neonatal mouse testes. $\mathrm{Na}$ ture 471: 504-507. doi:10.1038/nature09850

Schrans-Stassen BH, van de Kant HJ, de Rooij DG, van Pelt AM. 1999. Differential expression of c-kit in mouse undifferentiated and differentiating type A spermatogonia Endocrinology 140: 5894-5900. doi:10.1210/endo.140.12 .7172

Sharma M, Braun RE. 2018. Cyclical expression of GDNF is required for spermatogonial stem cell homeostasis. Development 145: dev151555. doi:10.1242/dev .151555

Sharma M, Srivastava A, Fairfield HE, Bergstrom D, Flynn WF, Braun RE. 2019. Identification of EOMES-expressing spermatogonial stem cells and their regulation by PLZF. eLife 8: e43352. doi:10.7554/eLife.43352

Sheng XR, Matunis E. 2011. Live imaging of the Drosophila spermatogonial stem cell niche reveals novel mechanisms regulating germline stem cell output. Development 138: 3367-3376. doi:10.1242/dev.065797

Sheng XR, Brawley CM, Matunis EL. 2009. Dedifferentiating spermatogonia outcompete somatic stem cells for niche occupancy in the Drosophila testis. Cell Stem Cell 5: 191203. doi:10.1016/j.stem.2009.05.024
Simons BD, Clevers H. 2011. Strategies for homeostatic stem cell self-renewal in adult tissues. Cell 145: 851-862. doi:10 $.1016 /$ j.cell.2011.05.033

Snippert HJ, van der Flier LG, Sato T, van Es JH, van den Born M, Kroon-Veenboer C, Barker N, Klein AM, van Rheenen J, Simons BD, et al. 2010. Intestinal crypt homeostasis results from neutral competition between symmetrically dividing Lgr5 stem cells. Cell 143: 134-144. doi:10.1016/j.cell.2010.09.016

Song HW, Wilkinson MF. 2014. Transcriptional control of spermatogonial maintenance and differentiation. Semin Cell Dev Biol 30: 14-26. doi:10.1016/j.semcdb.2014.02 .005

Spradling A, Fuller MT, Braun RE, Yoshida S. 2011. Germline stem cells. Cold Spring Harb Perspect Biol 3: a002642. doi:10.1101/cshperspect.a002642

Stine RR, Matunis EL. 2013. Stem cell competition: finding balance in the niche. Trends Cell Biol 23: 357-364. doi:10 $.1016 /$ j.tcb.2013.03.001

Suzuki S, Diaz VD, Hermann BP. 2019. What has singlecell RNA-Seq taught us about mammalian spermatogenesis? Biol Reprod 101: 617-634. doi:10.1093/biolre/ ioz088

Tabib T, Morse C, Wang T, Chen W, Lafyatis R. 2018. SFRP2/DPP4 and FMO1/LSP1 define major fibroblast populations in human skin. J Invest Dermatol 138: 802 810. doi:10.1016/j.jid.2017.09.045

Takase HM, Nusse R. 2016. Paracrine Wnt/B-catenin signaling mediates proliferation of undifferentiated spermatogonia in the adult mouse testis. Proc Natl Acad Sci 113: E1489-E1497. doi:10.1073/pnas.1601461113

Takeda N, Jain R, LeBoeuf MR, Wang Q, Lu MM, Epstein JA. 2011. Interconversion between intestinal stem cell populations in distinct niches. Science 334: 1420-1424. doi:10 $.1126 /$ science. 1213214

Taylor G, Lehrer MS, Jensen PJ, Sun TT, Lavker RM. 2000. Involvement of follicular stem cells in forming not only the follicle but also the epidermis. Cell 102: 451-461. doi:10.1016/S0092-8674(00)00050-7

Tokue M, Ikami K, Mizuno S, Takagi C, Miyagi A, Takada R, Noda C, Kitadate Y, Hara K, Mizuguchi H, et al. 2017. SHISA6 confers resistance to differentiation-promoting wnt/ $\beta$-catenin signaling in mouse spermatogenic stem cells. Stem Cell Rep 8: 561-575. doi:10.1016/j.stemcr .2017.01.006

Wang L, Siegenthaler JA, Dowell RD, Yi R. 2016. Foxcl reinforces quiescence in self-renewing hair follicle stem cells. Science 351: 613-617. doi:10.1126/science aad5440

Watt FM, Hogan BL. 2000. Out of Eden: stem cells and their niches. Science 287: 1427-1430. doi:10.1126/science.287 .5457 .1427

Yamashita YM, Fuller MT, Jones DL. 2005. Signaling in stem cell niches: lessons from the Drosophila germline. J Cell Sci 118: 665-672. doi:10.1242/jcs.01680

Yoshida S. 2012. Elucidating the identity and behavior of spermatogenic stem cells in the mouse testis. Reproduction 144: 293-302. doi:10.1530/REP-11-0320

Yoshida S. 2016. From cyst to tubule: innovations in vertebrate spermatogenesis. Wiley Interdiscip Rev Dev Biol 5: 119-131. doi:10.1002/wdev.204 
S. Yoshida

Yoshida S. 2018a. Open niche regulation of mouse spermatogenic stem cells. Dev Growth Differ 60: 542-552. doi:10 $.1111 /$ dgd.12574

Yoshida S. 2018b. Regulatory mechanism of spermatogenic stem cells in mice: their dynamic and context-dependent behavior. In Reproductive \& developmental strategies (ed. Kobayashi K, Kitano T, Iwao Y, Kondo M), pp. 47-67. Springer, Tokyo.

Yoshida S. 2019. Heterogeneous, dynamic, and stochastic nature of mammalian spermatogenic stem cells. Curr Top Dev Biol 135: 245-285. doi:10.1016/bs.ctdb.2019.04 .008
Yoshida S, Takakura A, Ohbo K, Abe K, Wakabayashi J, Yamamoto M, Suda T, Nabeshima Y. 2004. Neurogenin3 delineates the earliest stages of spermatogenesis in the mouse testis. Dev Biol 269: 447-458. doi:10.1016/j.ydbio.2004.01.036

Yoshida S, Nabeshima Y, Nakagawa T. 2007a. Stem cell heterogeneity: actual and potential stem cell compartments in mouse spermatogenesis. Ann NY Acad Sci 1120: $47-$ 58. doi:10.1196/annals.1411.003

Yoshida S, Sukeno M, Nabeshima Y. 2007b. A vasculatureassociated niche for undifferentiated spermatogonia in the mouse testis. Science 317: 1722-1726. doi:10.1126/ science.1144885 


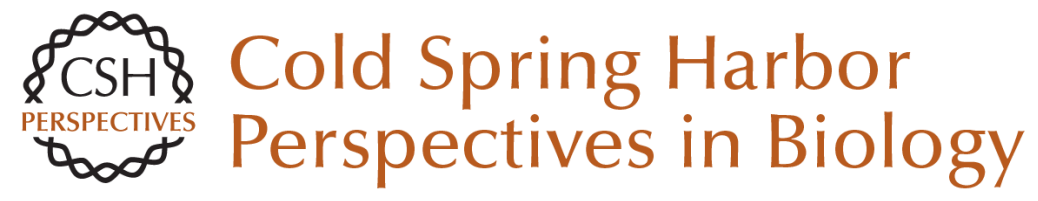

\section{Mouse Spermatogenesis Reflects the Unity and Diversity of Tissue Stem Cell Niche Systems}

Shosei Yoshida

Cold Spring Harb Perspect Biol 2020; doi: 10.1101/cshperspect.a036186 originally published online March 9, 2020

\section{Subject Collection Stem Cells: From Biological Principles to Regenerative Medicine}

A Stem Cell Approach to Cure Type 1 Diabetes Aharon Helman and Douglas A. Melton

Niche Cells and Signals that Regulate Lung Alveolar Stem Cells In Vivo

Nicholas H. Juul, Courtney A. Stockman and Tushar J. Desai

Stem Cell DNA Damage and Genome Mutation in the Context of Aging and Cancer Initiation Lara Al zouabi and Allison J. Bardin

Capturing Stem Cell Behavior Using Intravital and Live Cell Microscopy

Arianna Fumagalli, Lotte Bruens, Colinda L.G.J. Scheele, et al.

Brain Organoids: Human Neurodevelopment in a Dish

Silvia Benito-Kwiecinski and Madeline A. Lancaster

Advancing Stem Cell Research through

Multimodal Single-Cell Analysis

Iwo Kucinski and Berthold Gottgens

Tracing the Dynamics of Stem Cell Fate Lemonia Chatzeli and Benjamin D. Simons
Mouse Spermatogenesis Reflects the Unity and Diversity of Tissue Stem Cell Niche Systems Shosei Yoshida

A Synthesis Concerning Conservation and Divergence of Cell Types across Epithelia Daniel T. Montoro, Adam L. Haber, Jennifer E. Rood, et al.

Discovering New Progenitor Cell Populations through Lineage Tracing and In Vivo Imaging Rudra Nayan Das and Karina Yaniv

Next-Generation Biomaterials for Culture and Manipulation of Stem Cells

Koichiro Uto, Christopher K. Arakawa and Cole A. DeForest

Development of Stem Cell Therapies for Retinal

Degeneration Emma L. West, Joana Ribeiro and Robin R. Ali

Direct Lineage Reprogramming: Harnessing Cell

Plasticity between Liver and Pancreas Silvia Ruzittu, David Willnow and Francesca M. Spagnoli

Modeling Brain Disorders Using Induced

Pluripotent Stem Cells

Krishna C. Vadodaria, Jeffrey R. Jones, Sara

Linker, et al.

For additional articles in this collection, see http://cshperspectives.cshlp.org/cgi/collection/

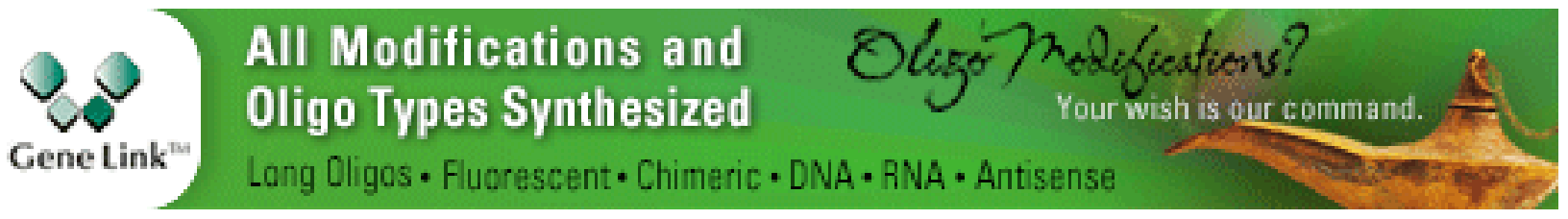


Toward Combined Cell and Gene Therapy for

\section{Genodermatoses}

Laura De Rosa, Maria Carmela Latella, Alessia Secone Seconetti, et al.

\section{Specification of the First Mammalian Cell \\ Lineages In Vivo and In Vitro \\ Melanie D. White and Nicolas Plachta}

For additional articles in this collection, see http://cshperspectives.cshlp.org/cgi/collection/

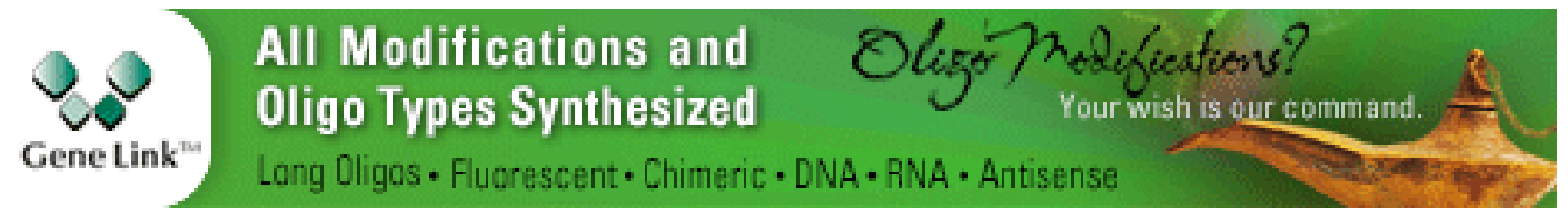

Copyright @ 2020 Cold Spring Harbor Laboratory Press; all rights reserved 